\title{
KARJOJEN LAADULLISISTA EROISTA
}

\author{
Mikko Varo \\ Maatalouskoelaitoksen kotieläinjalostusosasto, Tikkurila.
}

Saapunut 20. 11. 1953.

Vastauksen löytäminen kysymykseen, missä määrin karjojen keskituotokset pystyvät osoittamaan niiden välisiä laadullisia eroja tai kuinka ratkaisevasti ympäristötekijät määräävät karjojen tuotostason, on käytännöllisen jalostustoiminnan kannalta mitä tärkeintä. Paitsi, että siten saadaan selvyyttä siitoseläinten arvostelun menettelytapoihin, ennen muuta siihen, tuleeko valinnan perustua suhteelliseen vai absoluuttiseen arvosteluun, on myös mahdollista saada ohjeeksi keskiarvolukuja, jotka selvittävät, kuinka suuressa määrässä karjojen väliset keskituotoserot voidaan ottaa huomioon siitoseläinten laatua arvioitaessa. Tekijän aikaisemmat tutkimukset (16) näyttivät viittaavan siihen, että sonnien valinnassa on absoluuttista arvostelutapaa käytettäessä onnistuttu maidontuotantoon nähden yleensä sitä huonommin, mitä suurituotoksisemmista karjoista valinta on tapahtunut. Selitys on ilmeisesti siinä, että karjojen väliset laadulliset erot eivät ole läheskään niin suuret kuin keskituotokset näyttävät osoittavan, joten vain absoluuttilukuihin nojautuvassa valinnassa siitoseläimiksi valitaan ensisijassa edullisissa tuotanto-olosuhteissa olleita eläimiä riippumatta siitä, ovatko ne olleet hyviä vai huonoja saman karjan muihin eläimiin verrattuna. Tuotosten suuruus on kuitenkin yksilön tuottamiskyvyn ohella erittäin suuressa määrässä riippuvainen ruokinnasta ja hoidosta. Niinpä eräissä tanskalaisissa kokeissa (4) voitiin samojen yksilöiden tuotoksia ruokintatapaa muuttamalla nostaa edellisen vuoden tasoon verrattuna jopa yli kaksinkertaisiksi. Myös käytännöstä voidaan löytää esimerkkejä siitä, kuinka karjan tuotostaso lyhyessä ajassa voidaan meidänkin oloissamme nostaa varsin paljon aikaisemmasta tasosta ilmeisesti vain ruokintaa kehittämällä (17). Tällaiset kokemukset osoittavat, että keskimääräisissä tuotantoolosuhteissa ei ruokinta ole niin järjestetty, että eläinten koko tuotantokyky tulisi täydellä teholla hyväksi käytetyksi. Eläinten laatuerojen täytyy sen vuoksi suureksi osaksi perustua muihin syihin kuin niiden maksimaaliseen tuotantokykyyn. Näyttää välttämättömältä, että karjoissa havaittavien yksilöllisten laatuerojen tärkeimmät perusteet on löydettävissä eläinten erilaisesta rehujen hyväksikäytöstä, syöntikyvystä, ruokahalusta tai muista samantapaisesti vaikuttavista syistä. PoIJÄRvI (10) on maininnut, että lehmäyksilön erilainen sulatuskyky voi aiheuttaa 6 (KELL- 
NERin mukaan 9) prosentin poikkeaman keskimääräisestä tuotantokyvystä ja sulaneen ravinnon hyväksikäyttökyky 10 prosentin poikkeaman. Nämä seikat yhdessä saattaisivat vaikuttaa siis jopa $16-19 \%$ poikkeaman keskimääräisestä tuotantokyvystä. Omien laskelmieni mukaan Suomen Ayshireyhdistyksen 50-tonnin lehmien luettelossa olevien eläinten 10 ensimmäisen tuotantovuoden keskimääräiset suhteelliset arvot saattavat hajonnan perusteella laskien poiketa keskitasosta enintään n. $30-35 \%$. Tästä muuntelusta ilmeisesti sangen huomattava osa, ehkä siis puolet, voi perustua yksilöiden erilaiseen rehun sulatuskykyyn tai sulaneen ravinnon hyväksikäyttökykyyn. Koska nämä tekijät vaikuttavat siten, että yksilöt rehun energiayksikköä kohti tuottavat erilaisia maitomääriä, eivät tietyt rehun määrien tai laadun muutokset aiheuta eri yksilöillä kilomääräisesti vaan prosenttisesti samanlaisia tuotannonmuutoksia. Tämän perusteella voidaan prosenttisesti laskettuja suhteellisia arvoja pitää tarkoituksenmukaisimpina. Kun muidenkin yksilön laatuun vaikuttavien biologisten tekijöiden joukossa on epäilemättä samalla tavoin vaikuttavia, täytynee prosenttista arvostelua yleensäkin pitää sopivimpana. Seuraavassa tutkimuksessa on laskut kuitenkin suoritettu kilomääräisistä suhteellisista arvoista, koska niiden saanti nykyisestä tarkkailukirjanpidosta on ollut, päinvastoin kuin prosenttisten arvojen, ilman suuria laskutöitä mahdollista. Lopputuloksista on kuitenkin, silloin kun se on ollut mahdollista, laskettu myös prosenttisia arvoja likimain vastaavat tulokset.

On kuitenkin ilmeistä, että karjojen laadullisten erojen osuus keskituotosten kokonaiseroista on suuressa määrin olosuhteista riippuva. JoHANsson (5) on maininnut karjojen laadullisen muuntelun osuuden kokonaismuuntelusta, niiden heritabiliteetin, olevan noin 0.1 eli $10 \%$, mutta arvelee erojen suurissa karjoissa olevan hyvin pieniä. Bonnier (1) on päätynyt tulokseen 0.08 , mutta arvelee sen voivan olla suurempikin, enintään kuitenkin 0.16. RoBERTSON JA AskER (11) ovat saaneet laadullisen muuntelun osuudeksi 0.07. SKJERwold (12) mainitsee vastaavaksi arvoksi 0.15. KoRKMAN (7) on päätynyt melkoisesti suurempiin lukuihin. Ruotsalaisille SRB- ja SLB-roduille hän sai maidontuotannossa arvot 0.20 ja 0.27 ja maidon rasvapitoisuudessa 0.15 ja 0.27 . Edellä mainituissa tutkimuksissani olen arvioinut karjojen laadullisen muuntelun olevan meillä karjojen suuruudesta riippuen 14-20\% keskituotosten kokonaismuuntelusta. Koska arvio kuitenkin perustui käsitykseen, että karjojen väliset laatuerot johtuvat eri arvoisten eläinten sattumavaraisesta jakaantumisesta niihin, on seuraavassa pyritty toisin, käytännöllisemmin keinoin saamaan selvyyttä asiaan. Pääasiassa on tutkimuksessa pyritty selvittämään karjojen laatuerojen suuruutta maidontuotantotaipumuksen osalta, joskin lyhyesti on tarkasteltu myös havaittuja eroja maidon rasvapitoisuuksissa.

\section{Aineisto ja tutkimusmenetelmä}

Toistaiseksi ei liene muuta keinoa karjojen laadullisten erojen tutkimiseksi kuin tarkastella, millä tavoin samat yksilöt suhtautuvat eri karjojen muihin yksilöihin. Jos sama yksilö saa eri karjoissa erilaisen suhteellisen arvon täytyy eron johtua karjojen erilaisesta laadullisesta tasosta. Vertaamalla näin todettuja eroja keskituotos- 
ten kokonaiseroihin, voidaan tehdä päätelmiä karjan laadullisten erojen osuudesta keskituotoseroihin. Parhaiten tällaiset vertailut voitaisiin suorittaa identtisillä kaksosilla. Siihen ei meillä kuitenkaan ainakaan toistaiseksi ole riittävää aineistoa. Samojen lehmien eri karjoissa antamat tuotokset olisivat niin ikään käyttökelpoisia, mutta koska tulokset eri karjoissa olisi saatu eri-ikäisinä, eivät ne ilman muuta olisi vertailukelpoisia. Lisäksi tällaisten yksilöiden löytäminen on käytettävissä olevasta tilastoaineistosta sangen vaikeaa, joten tutkimuksessa on turvauduttu saman sonnin samanikäisten jälkeläisten vertailuun eritasoisissa karjoissa. Tutkittaviksi on valittu eri ayrshirekarjoista tarkkailuvuonna 1949-50 olleet ja v. 1945 syntyneet, eli keskimäärin n. 5-vuotiaat samojen sonnien jälkeläiset. Tämänikäisten yksilöiden valintaan on vaikuttanut, että niitä on muunikäisiin verrattuna ollut suhteellisen runsaasti ja mahdolliset tuotoserot, jotka johtuvat eri-ikäisenä tapahtuneesta ensipoikimisesta, ovat tähän mennessä jo menettäneet huomattavan osan merkityksestään. Niinikään ovat näin nuoret yksilöt vielä huomattavan säännöllisiä. Näin valittuja lehmiä on löydetty kaikkiaan 6342, joista vertailuun saatiin kuitenkin vain 5084. Saman sonnin jälkeläisiä on verrattu keskituotoksiltaan eritasoisissa karjoissa. Myös on verrattu tuloksia erikseen alle 10, 10-19 ja vähintään 20 lehmän karjoissa. Karjojen keskimääräinen laadullinen ero on laskettu siten, että jälkeläisten eri karjoissa saamien suhteellisten arvojen erotus on kerrottu kahdella. Näin on menetelty, koska jälkeläisryhmien laadullinen samankaltaisuus perustuu keskimäärin puoleen geenistöön ja suhteellisten arvojen keskiarvot voivat osoittaa senvuoksi vain puolet laadullisista eroista. Kilomääräisisțä suhteellisista arvoista laskettujen laadullisten erojen prosenttiosuus kokonaiseroista on laskettu prosenttina karjojen keskimääräisistä keskituotoseroista. Vastaava prosenttisista suhteellisista arvoista saatava luku on laskettu keskituotoserojen suhteellisesta arvosta, joka puolestaan on laskettu prosenttina alempitasoisten karjojen keskiarvosta. Tätä laskusuuntaa on pidetty oikeana, koska siitoseläinten hankinta vieraista karjoista tapahtunee säännöllisesti korkeammasta keskituotostasosta alempaan. On huomattava, että prosenttisista suhteellisista arvoista saadut tulokset on laskettu vasta keskituloksista, joten niitä voidaan pitää vain summittaisina arvoina.

Mikäli sonnin jälkeläisiä on ollut useammassa kuin kahdessa karjassa, on sama jälkeläinen saattanut joutua vertailuun useamminkin kuin kerran, jos karjat ovat olleet eri keskituotosluokissa. Tällainen menettely on lisännyt vertailumahdollisuuksia pienissä karjoissa, joissa on käytetty paljon yhtymien sonneja. Suurissa karjoissa sen sijaan on yleensä omien sonnien käyttö johtanut siihen, että saman sonnin jälkeläisiä on ollut sangen vaikea löytää eri karjoista. Pienissä, enintään 9 lehmän karjoissa saatiin 4205, keskikokoisissa, 10-19 lehmän karjoissa 561 ja suurissa 318 yksilöä vertailuun. Vaikka aineisto on kerätty kaikista ayrshirerotuisista tarkkailukarjoista, on se jäänyt näin pieneksi, koska puutteellisten merkintöjen vuoksi suuri osa eläimistä joudutaan karsimaan. Lehmät on näet poimittu sonnien jälkeläisarvosteluaineistosta, joka käsittää kantakirjasonnien kaikki jälkeläiset, joista on täydelliset tiedot maatalouskoelaitoksen kotieläinjalostusosastolle lähetetyissä raporteissa. Näiden raporttien merkinnöissä esiintyy niin paljon epätäydellisyyttä, että koko valtakunnan tarkkailukarjojen lehmistä lähes puolet on 
pakko jättää käsittelyn ulkopuolelle. Suurimpana syynä tähän on tarkkailukarjojen nopea vaihtuminen, minkä vuoksi suuresta osasta eläimiä ei ole kaikkia tarpeellisia tietoja saatavissa. Tämä on kieltämättä epäkohta, jonka poistamiseen olisi kaikin keinoin pyrittävä, koska se tuntuvasti vähentää koko tarkkailutoiminnan arvoa. Eräin kohdin täydennettiinkin tutkimusta siten, että suoritettiin rinnakkaisvertailuja melkoisesti suuremmalla 7-11-vuotiaita yksilöitä käsittävällä puolisisaraineistolla, kuten myöhemmin selostetaan.

\section{Karjojen laadullisten erojen osuus maitokeskituotosten kokonaiseroista}

Koko aineistosta saadut tulokset on esitetty taulukossa 1. Keskimääräisistä tuotoksista voidaan todeta, että samojen sonnien jälkeläiset eivät alemmassa keskituotostasossa varmasti poikkea karjojensa keskiarvoista, mutta ylemmässä tasossa ne jäävät selvästi keskitason alapuolelle. Eritasoiset karjat ovat siten ilmeisesti laadultaan erilaisia. Suhteellisten arvojen erotus osoittaa, että saman sonnin jälkeläiset ovat eri tuotostasoissa saavuttaneet selvästi erilaisen aseman karjoissaan. Tulos riittänee osoittamaan, että eritasoisten karjojen välillä on todellisia laadullisia eroja, mutta että ne ovat huomattavasti pienemmät kuin keskituotosten kokonaiseroista voisi päätellä. Edellä selostettua laskutapaa käyttäen tullaan tulokseen, että karjojen laatuerot ovat koko aineistossa keskimäärin $15.3 \%$ keskituotosten kokonaiseroista. Prosenttisia suhteellisia arvoja käytettäessä olisivat laatuerot vain n. $11 \%$.

Keskimäärin on tulos hyvin yhdenmukainen aikaisemmin suorittamani arvion kanssa, jonka mukaan karjojen laadullinen muuntelu vaihteli rajoissa $14-20 \%$ kokonaismuuntelusta, niinkuin edellä jo on mainittu. Ne tulokset oli laskettu kilomääräisinä erotuksina ilmaistuista suhteellisista arvoista, joista nyt saatiin arvo $15.3 \%$.

Taulukko 1. Samojen sonnien 5-vuotiaiden jälkeläisten asema eritasoisissa karjoissa.

Tabelle 1. Die Stellung 5jähriger Nachkommen derselben Bullen in Herden verschiedenen Niveaus.

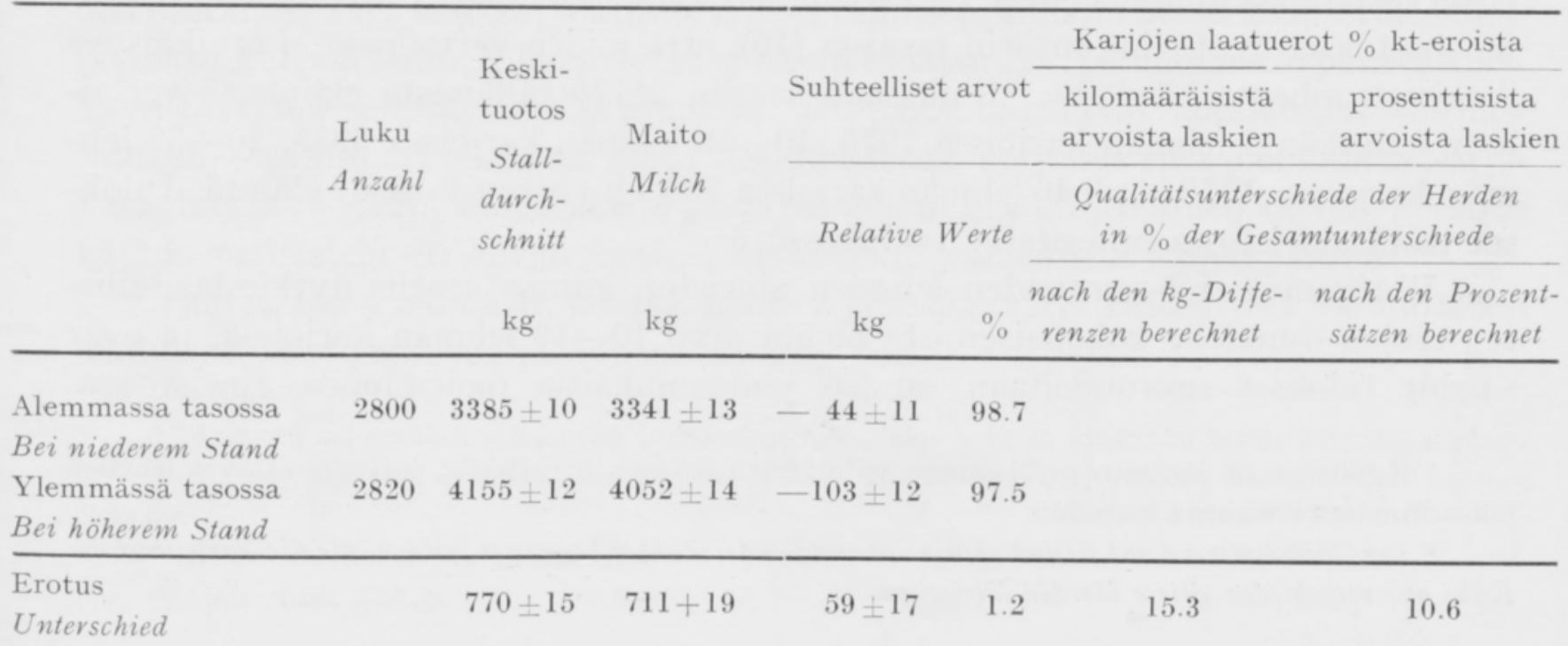


Taulukko 2. Karjojen laatuerot eri suurissa karjoissa (5-vuotiaiden jälkeläisten aineisto) Tabelle 2. Die Qualitätsunterschiede der Herden bei verschieden grossen Herden (Material 5jähriger Nachkommen).

\begin{tabular}{|c|c|c|c|c|c|}
\hline \multirow{5}{*}{$\begin{array}{c}\text { Karjojen } \\
\text { lehmäluku } \\
\text { Anzahl der } \\
\text { Kühe in den } \\
\text { Herden }\end{array}$} & \multirow{5}{*}{$\begin{array}{l}\text { Keskituotos- } \\
\text { ten erot } \\
\text { Unterschiede } \\
\text { der Stall- } \\
\text { durchschnitte } \\
\text { kg }\end{array}$} & \multirow{4}{*}{\multicolumn{2}{|c|}{$\begin{array}{l}\text { Suhteellisten } \\
\text { arvojen erot } \\
\text { Unterschiede } \\
\text { der relativen } \\
\text { Werte }\end{array}$}} & \multicolumn{2}{|c|}{ Karjojen laatuerot \% kt-eroista } \\
\hline & & & & \multirow{2}{*}{$\begin{array}{l}\text { kilomääräisistä } \\
\text { erotuksista laskien }\end{array}$} & \multirow{2}{*}{$\begin{array}{l}\text { prosenttisista } \\
\text { arvoista laskien }\end{array}$} \\
\hline & & & & & \\
\hline & & & & \multicolumn{2}{|c|}{$\begin{array}{l}\text { Qualitätsunterschiede der Herden } \\
\text { in } \% \text { der Gesamtunterschiede }\end{array}$} \\
\hline & & $\mathrm{kg}$ & $\%$ & $\begin{array}{l}\text { nach den } k g-D i f f e- \\
\text { renzen berechnet }\end{array}$ & $\begin{array}{l}\text { nach den prozentu- } \\
\text { alen Werten berechnet }\end{array}$ \\
\hline-9 & $719 \pm 18$ & $37 \pm 18$ & 0.7 & 10.3 & 6.5 \\
\hline $10-19$ & $619 \pm 41$ & $19 \pm 55$ & 0.4 & 6.2 & 4.6 \\
\hline \multirow[t]{2}{*}{20} & $907 \pm 60$ & $236 \pm 81$ & 4.9 & 52.0 & 40.7 \\
\hline & $\begin{array}{l}\text { Lehmien sul } \\
\text { Im Verhälts }\end{array}$ & $\begin{array}{l}\text { dessa kesk } \\
\text { derhe }\end{array}$ & täri & tlich 1) & 15.4 \\
\hline
\end{tabular}

Kun tulokset laskettiin erikseen eri suurista karjoista, olivat ne siinä suhteessa yllättäviä, että päinvastoin kuin voitiin odottaa, näyttääkin karjojen laadullisten erojen osuus kokonaiseroista suurissa karjoissa olevan suurempi kuin pienissä. Karjojen laadullisten erojen suuruuden ei siis voidakaan olettaa riippuvan, kuten olin aikaisemmin menetellyt, pääasiassa erilaisten eläinten sattumanvaraisesta sijoittumisesta karjoihin, jolloin pienten karjojen laadulliset erot muodostuisivat tietenkin suuremmiksi kuin suurten. Tuloksiin, jotka on esitetty taulukossa 2, on siten täytynyt olla vaikuttamassa muitakin syitä. Mielenkiintoisin on saatu tulos siinä suhteessa, että laatuerot eivät näytä kasvavan suoraviivaisesti karjojen suuretessa, vaan laadullisten erojen osuus kokonaiseroista näyttää olevan pienin 10-19 lehmän karjoissa. Koska aineiston pienuuden vuoksi tulos on epävarma siinä mielessä, että suhteellisten arvojen erotukset karjojen eri suuruusluokissa eivät ole tilastollisesti varmoja, kerättiin tämän seikan varmistamiseksi yksinkertaisempaa menettelytapaa noudattaen aineisto, joka käsitti kaikki tarkkailuvuonna 1949-50 sonnien jälkeläisarvosteluissa mukana olleet 7-11-vuotiaat ayrshirelehmät. Tämänikäisten eläinten tuotokset ovat siinä määrin tasaisia (15), että niiden vertailussa ei eri-ikäisyys ilmeisesti aiheuta häiriöitä. Kaikkiaan saatiin 25775 tällaisesta eläimestä vertailuun enintään 9 lehmän karjoissa 7976, 10—19 lehmän karjoissa 3933, 20—39 lehmän karjoissa 1072 ja yli 40 lehmän karjoissa 706, eli yhteensä 13687 eläintä. Tulokset tästä aineistosta on esitetty taulukossa 3 .

Yhtäpitävästi 5-vuotiaiden lehmien aineiston kanssa saatiin nytkin laadullisten erojen osuudelle kokonaiseroista pienin arvo 10-19 lehmän karjoissa, ja ovat saadut tulokset suuruudeltaan sangen yhdenmukaisia molemmissa aineistoissa.

${ }^{1}$ Keskiarvo on laskettu myöhemmin esitettävien lukujen perusteella, jotka osoittavat lehmien jakaantumisen erisuuriin karjoihin.

1 Der Mittelwert ist auf Grund später darzustellender Zahlen berechnet worden, die die Verteilung der Kühe auf verschieden grosse Herden ausweisen. 
Taulukko 3. Karjojen laatuerot eri suurissa karjoissa (7-11-vuotiaiden jälkeläisten aineisto).

Tabelle 3. Die Qualitätsunterschiede der Herden bei verschieden grossen Herden (Material von 7-11jährigen Nachkommen).

\begin{tabular}{|c|c|c|c|c|c|c|c|c|}
\hline 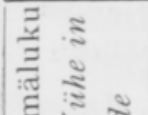 & $\overline{\bar{z}} \overline{\bar{n}}$ & $\begin{array}{l}\text { Keskit } \\
\text { Stalldur }\end{array}$ & $\begin{array}{l}\text { lotokset } \\
\text { chschnitte }\end{array}$ & $\begin{array}{l}\text { Maitot } \\
\text { Milchle }\end{array}$ & $\begin{array}{l}\text { 1otokset } \\
\text { istungen }\end{array}$ & 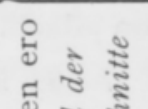 & ฮี & Karjojen laatuero \% \\
\hline 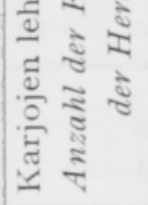 & 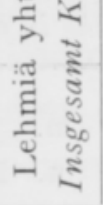 & 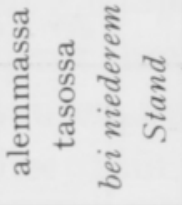 & 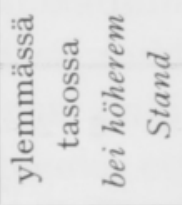 & 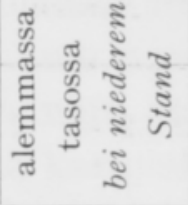 & 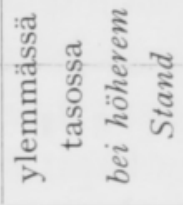 & 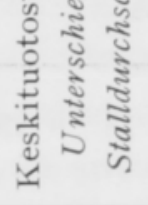 & 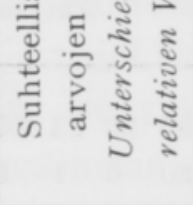 & $\begin{array}{l}\text { Qualitätsunterschied } \\
\text { der Herden in \% der } \\
\text { Gesamtunterschiede }\end{array}$ \\
\hline-9 & 7976 & $3325 \pm 7$ & $4118 \pm 9$ & $3509 \pm 12$ & $4258 \pm 13$ & $793 \pm 11$ & $44 \pm 14$ & 11.1 \\
\hline $10-19$ & 3933 & $3561 \pm 11$ & $4213 \pm 12$ & $3694 \pm 18$ & $4329 \pm 21$ & $652 \pm 16$ & $17 \pm 22$ & 5.2 \\
\hline $20-39$ & 1072 & $3696+22$ & $4320+27$ & $3871 \pm 39$ & $4403+43$ & $624 \pm 35$ & $92 \pm 47$ & 29.5 \\
\hline $40-$ & 706 & $3587 \pm 26$ & $4189 \pm 21$ & $3819 \pm 51$ & $4122 \pm 50$ & $602 \pm 33$ & $299 \pm 58$ & 99.3 \\
\hline
\end{tabular}

Vaikkakaan suhteellisten arvojen erotukset eivät keskikokoisissa karjoissa ole keskivirheisiin nähden varmoja — se johtuu aineiston pienuudesta, mutta suurempaa lehmämäärää ei tällaiseen vertailuun ole meidän oloissamme tällä hetkellä saatavissa —, on kuitenkin ilmeistä, että eritasoisten karjojen välillä on todellisia laadullisia eroja, jotka kuitenkin muodostavat kaikkein suurimpia karjoja lukuunottamatta vain pienen osan keskituotosten kokonaiseroista.

Etsittäessä syitä siihen, että karjojen laatuerot yleensä suurenevat lehmäluvun suuretessa, tulee ensimmäiseksi epäilleeksi, että pienissä karjoissa eivät suhteelliset arvot pysty osoittamaan eläinten laadullisia eroja täsmällisesti, eivätkä ne sen vuoksi soveltuisi myöskään nyt puheenaolevan tutkimuksen pohjaksi. Tämä ei kuitenkaan tunnu uskottavalta, koska suhteellisten arvojen hajonta pienissä karjoissa, kuten tuonnempana osoitetaan, ei ole niin paljon pienempi kuin suurissa, että se yksin riittäisi saatujen erojen syyksi. Ilmeisesti käytetty menetelmä antaa pienissä karjoissa kyllä liian pienen arvon laadullisille eroille, mutta näin syntyvä virhe ei voi olla niin suuri, että se yksin selittäisi saadut tulokset. Tähän viittaa sekin, ettälehmäluvun suuretessa laatuerojen kehitys ei näytä hidastuvan, pikemminkin päinvastoin. Syyn täytynee sen vuoksi olla muualla. Sitäpaitsi osoittavat laatuerojen suuruussuhteet — pienin arvo kun on saatu 10-19 lehmän karjoissa eikä pienimpien karjojen ryhmässä —, että lehmäluku ei yksin ole voinut olla erojen aiheuttajana. Sonnien käytön tarkastelu eri karjaryhmissä antaneekin valaistusta kysymykseen.

Taulukosta 4 nähdään, kuinka sonnien jälkeläiset nyt käsitellyssä 5-vuotiaiden lehmien aineistossa ovat jakaantuneet karjoihin.

1 Mainittu eläinmäärä jakaantuu jokseenkin tasan alemman ja ylemmän tason karjojen kesken.

1 Die angegebene Tiermenge verteilt sich ziemlich gleichmässig auf Herden niederen und höheren Standes.

2 Katso alaviittaa taulukossa 2.

2 Siehe Anm. Tab. 2. 
Taulukko 4. Sonnien 5-vuotiaiden jälkeläisten jakaantuminen karjoihin.

Tabelle 4. Die Verteilung der 5jährigen Nachkommen der Bullen auf die Herden.

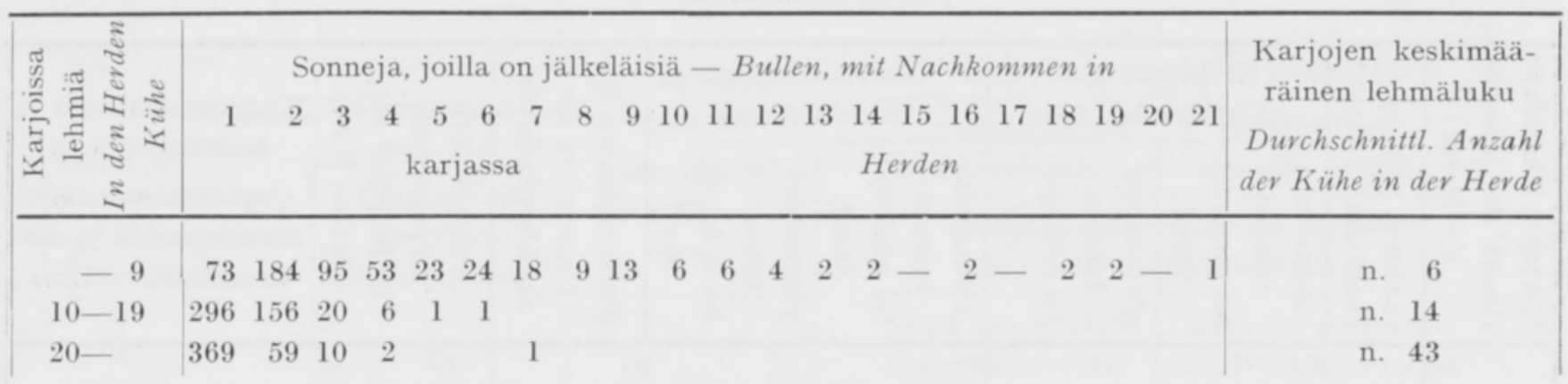

Keskimäärin on jälkeläisiä eri ryhmissä ollut 3.6, 1.5 ja 1.2 karjassa. Niiden sonnien osuus, joiden jälkeläiset ovat kaikki olleet samassa karjassa, on näissä eri karjaryhmissä ollut 14.1, 61.7 ja $83.7 \%$. Sonnien käyttö on siis eri ryhmissä ollut aivan erilaista, ja luvuista havaitaan, että pienten karjojen ryhmään on ilmeisesti joutunut pääasiassa sonninpitoyhtymiin kuuluvia karjoja. Sen sijaan muissa karjaryhmissä on yksityisten sonnien käyttö yleisempää ja ilmeisesti sitä suuremmassa määrässä, mitä suurempia karjat ovat. Pienten karjojen tasalaatuisuus saa nyt selityksensä siitä, että pitkäaikainen yhteisten sonnien käyttö on pienentänyt karjojen laadullisia eroja. Sen sijaan muissa karjoissa yksityiset sonnit ovat tehneet mahdolliseksi itsenäisemmän kehityksen. Tällainen päätelmä tuntuu sitäkin uskottavammalta kun otetaan huomioon, että pienissä karjoissa sonnien jalostuksellinen merkitys lehmiin verrattuna on ilmeisesti suurempi kuin suurissa. Suurissa karjoissa nimittäin on epäilemättä helpompi kuin pienissä sekä todeta parhaat lehmät että myös ottaa niistä vasikoita eloon niin paljon kuin karjan uudistaminen vaatii. Pienissä sen sijaan eläinten vaikeamman vertailun lisäksi sattuma, ennen muuta vasikoiden sukupuolisuhde, saattaa pahasti vaikeuttaa pitovasikoiden saantia niistä eläimistä, joista niitä eniten toivottaisiin.

Mutta miten on selitettävissä, että karjojen laadulliset erot pienimmistä suurempiin karjoihin siiryttäessä aluksi pienenevät ja vasta 20-lehmäisistä karjoista lähtien suurenevat? Tähän kehitykseen on kaikesta päättäen samanaikaisesti vaikuttanut sekä sonnien käyttötapa että karjojen suuruus mukanaan tuomine seuraamuksineen. Sonnien erilaista käyttötapaa eri suurten karjojen ryhmissä kuvaavat myös suuremmasta, 7-11 vuotiaiden lehmien aineistosta lasketut prosenttiluvut, jotka osoittavat, suuriko osa eläimistä kussakin ryhmässä tuli vertailuun mukaan, toisin sanoen, suuriko osa kaikista ryhmän eläimistä oli eri karjoissa olevia saman sonnin jälkeläisiä. Näiksi prosenttiluvuiksi saatiin pienissä, enintään 9 lehmän karjoissa $81.9 \%, 10$ - 19 lehmän karjoissa $50.3 \%, 20$-39 lehmän karjoissa $21.7 \%$ ja suurimpien karjojen ryhmässä $21.5 \%$. Yhteisten sonnien käyttö on siis jo toisessa ryhmässä selvästi vähentynyt, mikä ilmeni myös jo taulukosta 4, mutta siitä huolimatta ovat laadulliset erot pienempiä kuin pienissä karjoissa. Selitys lienee siinä, että yhteisten sonnien jälkeläisiä on vielä siksi huomattava osa kaikista yksilöistä, että sonnien laatueroja tasoittava vaikutus ei vielä ole sanottavasti menettänyt merkitystään. Samalla on karjojen suurentuminen kuitenkin vaikuttanut tasoitta- 
vasti laatueroihin, koska suuret eläinryhmät ovat laadullisesti keskenään samankaltaisempia kuin pienet. Jos ajatellaan yksilöiden sattumanvaraisesti sijoittuneen karjoihin ja oletetaan yksilöiden varianssin olevan 1, olisi näet pienten karjojen laadullinen varianssi, kun karjojen keskikoko oletetaan kuudeksi, 1/6, ja 10-19 lehmän karjojen varianssi, jos keskiarvoksi oletetaan 14, 1/14. Teoreettisesti olisi siis pienten karjojen laadullinen muuntelu noin kaksi kertaa suurempi kuin suurempien karjojen ryhmässä, mikä suurin piirtein vastaa saatuja tuloksia. Mutta vaikka karjojen suureneminen onkin näin tasoittanut laatueroja, ovat karjat kuitenkin edelleen olleet niin pieniä, että karjoissa tapahtuvaa siitosvalintaa ei ole voitu vielä saada niin tehokkaaksi, että se voittaisi sonnien tasoittavan vaikutuksen. Vasta yli 20 lehmän karjoissa alkaa valinnan onnistuminen olla siksi varmaa, että se on voinut selvästi vaikuttaa karjojen erilaistumiseen, mitä lisäksi yksilöllinen sonnien valinta on helpottanut.

Nyt todettu seikka, että laadullisten erojen osuus kokonaiseroista suurissa karjoissa on suurempi kuin pienissä, selittää varsin hyvin tekijän aikaisemmassa tutkimuksessaan (16) saaman ristiriitaisen tuloksen, jonka mukaan aineiston eräässä osassa saatiin emien keskituotosten ja poikien suhteellisten arvojen välille suurempi positiivinen korrelaatio (0.24) kuin emien ja poikien suhteellisten arvojen välille $(0.18)$, mutta kaikissa muissa tapauksissa osoittautui vanhempien keskituotos poikien suhteellisiin arvoihin sangen vähän vaikuttavaksi. Joka tapauksessa jäi keskituotoksen vaikutus yleensä vanhempien suhteellisiin arvoihin verrattuna perin heikoksi ja eräissä tapauksissa suunnaltaan jopa negatiiviseksi. Poikkeuksellinen tulos oli saatu sonniaineistosta, joka oli maatalouskoelaitoksen kotieläinjalostusosastolla arvosteltu pääasiassa jalostusyhdistysten pyynnöstä. Toinen osa aineistosta käsitti sensijaan kantakirjasonnien jälkeläisarvostelutuloksia kaikenlaisista tarkkailuyhdistyksiin kuuluvista ayrshirekarjoista. Tätä aineiston osaa voidaan pitää varsin tarkoin maan keskimääräisiä olosuhteita edustavana, sillä siihen sisältyvä lehmäaines käsitti noin viidenneksen tarkkailuyhdistyksiin silloin kuuluneista ayrshireeläimistä. Kun nyt saatujen tulosten jälkeen selvitettiin mainitun poikkeuksellisen tuloksen antaneen aineiston sonnien emien karjojen keskikoko, havaittiin emien melkein poikkeuksetta olleen suurten, vieläpä maamme olosuhteet huomioon ottaen hyvin suurten karjojen yksilöitä. Karjojen keskisuuruus oli näet 54 lehmää, kun se tarkkailukarjoissa on keskimäärin n. 7.5 ja ayrshirekarjoissakin arviolta enintään n. 10 lehmää. Pienempiä kuin 20 lehmän karjoja oli neljä ja näistäkin kaksi vain. tilapäisesti. Kaikkiaan 107 emästä oli 16 pienemmistä kuin 20 lehmän karjoista. Poikkeuksellinen tulos on siis epäilemättä johtunut vain siitä, että emät ovat olleet suurista karjoista, joiden laadullisten erojen osuus keskituotosten kokonaiseroista on ollut huomattavasti suurempi kuin kaikissa karjoissa keskimäärin.

Koska keskituotosten osuus emän arvon määrääjänä tässä poikkeuksellisessa aineistossa on ollut varsin suuri, jopa suurempi kuin suhteellisen arvon, mikä näkyy mainituista korrelaatioista, pitäisi suhteellisiin arvoihin ja keskituotoksiin yhteisesti perustuvan valinnan johtaa selvästi parempaan tulokseen kuin vain suhteelliseen arvoon perustuva. Tämä voitiinkin todeta, kun emien arvot määrättiin sekä suhteellisten arvojen että keskituotosten perusteella painottamalla näitä ensin yhtä 
paljon, sitten keskituotoksia kaksi kertaa enemmän kuin suhteellisia arvoja. Näin saatiin emien ja poikien suhteellisten arvojen väliseksi korrelaatioksi kumpaisessakin tapauksessa $0.31 \pm 0.09$. Maksimikorrelaatio olisi saatu, jos painotus olisi tapahtunut aikaisemmin mainittujen kertoimien 0.24 ja 0.18 suhteessa, mutta todennäköisesti tulos olisi kuitenkin poikennut vain vähän nyt saadusta arvosta. Täydennykseksi mainittakoon, että kun laskettiin molempien vanhempien ja poikien suhteellisten arvojen korrelaatio ja keskituotosten ja suhteellisten arvojen painotus vaihteli 2:1, $1: 1$ ja $1: 2$, saatiin kertointen arvoiksi $0.33,0.39$ ja 0.43 . Suhteellisen arvon painon lisääntymisen edullisuus johtuu siitä, että isien arvossa suhteellisella arvolla on ratkaisevasti suurempi merkitys kuin keskituotoksella - oikean painotuksen osoittavat korrelaatiot ovat näet suhteellisesta arvosta saatu 0.27 ja keskituotoksesta saatu 0.04. Edullisin tulos olisi siis saatu painottamalla isien arvoja suhteessa 0.24: 0.04 (eli n. 7:1) ja emien arvoja suhteessa 0.18:0.24 (eli 3:4). Nytkin saatu tulos kuitenkin osoittaa, että jalostustyötä voidaan viedä sangen tehokkaasti eteenpäin, jos siitoseläinten arvostelu perustetaan samanaikaisesti suhteellisiin arvoihin ja keskituotoksiin siinä suhteessa kuin näillä on vaikutusta yksilön laatuun ja sonnit valitaan sekä korkeatasoisista emistä että isistä.

Väärin ymmärtämisen välttämiseksi mainittakoon vielä, että tässä lähemmin tarkastellun poikkeuksellisen aineiston emien karjojen keskituotosten ja poikien suhteellisten arvojen korrelaation suurta arvoa ei ole käsitettävä niin, että nämä suurissa karjoissa olleet emät olisivat jättäneet vain hyviä jälkeläisiä. Korrelaation suuri arvo johtuu siitä, että karjat ovat laadultaan olleet hyvin erilaisia ja sen vuoksi on osa emistä vaikuttanut voimakkaasti positiiviseen, osa negatiiviseen suuntaan. Keskituotos ei vielä tällöinkään ole sellaisenaan kelvannut osoittamaan täsmällisesti karjojen laadullista tasoa, mutta sekä suhteellinen arvo että keskituotos yhdessä antavat jo varsin käyttökelpoisen kuvan yksilön laadusta.

Tulkoon vielä mainituksi, että esitetyllä tavalla saatu tulos, joka osoittaa karjojen laadullisten erojen olevan suurissa karjoissa yleensä suurempia kuin pienissä, voisi johtua myös siitä, että ympäristö, ts. tuotannon edellytykset ovat suurissa karjoissa keskimäärin tasaisemmat kuin pienissä. Tämä voi olla mahdollista syystä, että ruokinta suurissa karjoissa vain harvoin lienee toisaalta yksipuoliseen korsirehuun, toisaalta runsaaseen väkirehun käyttöön perustuvaa, mitkä äärimmäisyystapaukset pienissä karjoissa esiintynevät yleisemmin. Suurten karjojen eläinten käsittely ja hoito ei epäilemättä myöskään ole siinä määrin yksilöllistä kuin pienten karjojen. Nyt esitettyä mahdollisuutta tukevat eri karjaryhmien keskituotosten hajonnat, jotka olivat pienissä, keskikokoisissa ja suurissa karjoissa $636 \pm 9,582+12$ ja $620 \pm 19 \mathrm{~kg}$. Vaikka laatuerot aikaisemmin esitetyn mukaan suurenevatkin $10-19$ lehmän karjoja lukuunottamatta karjojen suuretessa, on keskituotosten suurin hajonta saatu pinten karjojen ryhmässä. On mahdollista, että laatuerojen suureneminen karjojen suuretessa on osaksi näennäistä ja perustuu suurten karjojen muita tasaisempiin tuotannon edellytyksiin. Niin merkityksellinen kuin asia kenties saattaisi ollakin, ei sen lähempään tutkimiseen nyt ole ryhdytty, koska se ei käytännössä sanottavasti vaikuta siitoseläinten valinnan menettelytapoihin. 
Taulukko 5. Maidon ja rasvaprosentin suhteellisten arvojen vuorosuhteet ja hajonnat.

Tabelle 5. Korrelationen und Streungen der relativen Werte der Milch und des Fettprozents.

\begin{tabular}{|c|c|c|c|c|c|c|}
\hline \multirow{2}{*}{$\begin{array}{c}\text { Karjojen } \\
\text { lehmäluku } \\
\text { Anzahl der } \\
\text { Kühe in der } \\
\text { Herde }\end{array}$} & \multicolumn{3}{|c|}{$\begin{array}{c}\text { Kaikki lehmät } \\
\text { Alle Kühe }\end{array}$} & \multicolumn{3}{|c|}{$\begin{array}{l}\text { Säännölliset lehmät } \\
\text { Regelmässige Kühe }\end{array}$} \\
\hline & $\mathrm{r}$ & $\begin{array}{l}\text { maidon s } \\
s \text { der Milch }\end{array}$ & $\begin{array}{c}\text { rasvan s } \\
\text { s des Fettes }\end{array}$ & $\mathrm{r}$ & $\begin{array}{l}\text { maidon s } \\
\text { s der Milch }\end{array}$ & $\begin{array}{c}\text { rasvan s } \\
s \text { des Fettes }\end{array}$ \\
\hline-9 & $-0.24 \pm 0.02$ & $592 \pm 8$ & $0.32 \pm 0.004$ & $-0.23 \pm 0.02$ & $581 \pm 8$ & $0.31 \pm 0.004$ \\
\hline $10-19$ & $-0.27 \pm 0.02$ & $693 \pm 11$ & $0.32 \pm 0.005$ & $-0.26 \pm 0.02$ & $661 \pm 11$ & $0.31 \pm 0.005$ \\
\hline $20-$ & $-0.24 \pm 0.02$ & $718 \pm 12$ & $0.32 \pm 0.005$ & $-0.22 \pm 0.02$ & $694 \pm 12$ & $0.31 \pm 0.005$ \\
\hline
\end{tabular}

Aikaisemmin esitetyistä luvuista jo on käynyt ilmi, että karjojen suuruus sinänsä ei ilmeisesti ole esteenä toisaalta eläinten suhteelliselle arvostelulle, toisaalta karjojen laadullisten erojen tutkimiselle. Karjojen pienuuden vaikutus lähinnä siten, että yksilöiden suhteellisten arvojen hajonta pienenee, mutta niiden kyky erottaa hyvät ja huonot yksilöt toisistaan säilyy jokseenkin muuttumattomana, käy ilmi myös vuorosuhteista, jotka eri karjakokoryhmissä on laskettu maidon ja rasvaprosentin suhteellisista arvoista taulukkoon 5 .

Vuorosuhteet ovat siis kaikissa ryhmissä yhtä suuret. Se osoittaa, €ttä suhteellisilla tuotosluvuilla on yksilön laadun osoittajina sama merkitys kaikensuuruisissa karjoissa. Jos niin ei olisi, ei pienissä karjoissa voisi vuorosuhde olla sama kuin muissa. Eläinten pienemmästä hajonnasta niissä johtuu kuitenkin, että parhaat eläimet saavat pienissä karjoissa keskimäärin hieman pienempiä arvoja kuin samanarvoiset yksilöt suurissa karjoissa ja vastaavasti heikoimmat yksilöt parempia, toisin sanoen liian hyviä arvoja. Näin syntyvä virhe on kuitenkin vähäinen, eikä se merkitse mitään heikompien yksilöiden kohdalla, koska näitä ei yleensä käytetä siitokseen. Parhaiden eläinten arvostelussa ei haitta myöskään liene merkittävä, jos lähdetään siitä, että pienissä karjoissa lasketut arvot ovat jonkinverran muita epävarmempia, joten niille näin tulee asetettavaksi hieman ankarammat vaatimukset kuin muille.

Merkille pantavaa muten on, että rasvaprosenttien hajonta on kaikissa ryhmissä ollut yhtä suuri. Jos rasvaprosentin periytyminen todella on niin yksinkertaista - ainakin valtaosaltaan — kuin v. PATow (9) on esittänyt, on asia ymmärrettävissä. Voisi näet olettaa, että yksilöiden laadullinen muuntelu on niin vähäistä, että pienimpienkin karjojen ryhmässä, jossa keskimääräinen lehmäluku on ainakin 6 , on yhteisten sonnien ansiosta kaikenlaatuisten yksilöiden esiintyminen osapuilleen normaalissa lukusuhteessa mahdollista.

Maitotuotosten hajonta on sensijaan pienissä karjoissa $82.5 \%$ ja keskikokoisissa $96.5 \%$ suurten karjojen yksilöiden hajonnasta. Tämä suhde osoittaa, että pienille karjoille laskelmissa saadut pienet laadulliset erot eivät voi olla vain suhteellisten arvojen epätarkkuudesta johtuvia, joskin saatu arvo on ilmeisesti todellista hieman alhaisempi. Käytetystä laskutavasta johtuen karjojen pienuus aiheuttaa laatueroihin näet varianssin eroja vastaavan virheen. Mutta kun muistetaan, että 
saman sonnin jälkeläisten osuus karjan koko lehmäluvusta on pienissä karjoissa vain vähän suurempi kuin suurissa - tekijän aikaisemmissa tutkimuksissa (16) oli saman sonnin jälkeläisiä —9 lehmän karjoissa $23 \%, 10-19$ lehmän karjoissa $171 \%, 20-29$ lehmän karjoissa $14 \%$ ja vähintään 40 lehmän karjoissa $12 \%$ kaikista lehmistä —, voidaan todeta, että tulosten oikaiseminen varianssin eroilla ei merkitsevästi muuttaisi laatuerojen suhteita.

\section{Laatuerojen riippuvuus keskituotoserojen suuruudesta}

Aineisto ryhmitettiin myös siten, että voitiin verrata eri suuria keskituotoseroja vastaavia laatueroja toisiinsa. Taulukkoon 6 on koottu tästä vertailusta saadut tulokset.

Suurten keskituotoserojen ryhmissä on yksilöiden määrä niin pieni, että laatuerojen muutoksille ei voida antaa kovinkaan suurta merkitystä. Kehitys osoittaa kuitenkin, että laatuerot eivät ainakaan suurene keskituotoserojen suuretessa, näyttäväthän ne päinvastoin pienenevän. Tosin laatuerojen pieneneminen johtunee todennäköisimmin eri suurten karjojen lukusuhteen muuttumisesta eri ryhmissä, sillä suurimmat keskituotoserot on helpommin löydettävissä pienistä karjoista. Taulukon 6 tulos viittaa siihen, että yksilön suurimman mahdollisen tuotantokyvyn selvittäminen ei siitosvalinnassa ole tärkeää. Jos näet sillä olisi huomattavaa merkitystä, pitäisi laatuerojen päin vastoin keskituotoserojen suuretessa kasvaa. Silloin nimittäin muodostuisi suurimman tuotantokyvyn raja suuremmassa keskituotostasossa tuotantoa rajoittavaksi tekijäksi sitä useammin, mitä enemmän keskituotokset poikkeavat toisistaan niissä karjoissa, joissa vertailua suoritetaan. Tämä taas puolestaan suurentaisi laatueroja, kun laskenta suoritetaan nyt käytetyllä tavalla. Vähintään 20 lehmän karjojen ryhmässä, missä laatuerot olivat selvimmät, oli niiden osuus kuitenkin sangen yhdenmukainen kaikissa keskituotoseroryhmissä. Noin 500, 1000 ja $1500 \mathrm{~kg}: \mathrm{n}$ keskituotoseroja vastaavat laatueroprosentit olivat

Taulukko 6. Karjojen laatuerojen riippuvuus keskituotoseroista.

Tabelle 6. Die Abhängigkeit der Qualitätsunterschiede der Herden von den Unterschieden der Stalldurchschnitte.

\begin{tabular}{|c|c|c|c|c|c|c|c|c|c|}
\hline 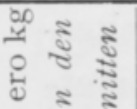 & 胥 & & $\begin{array}{l}\text { Suhteell } \\
\text { Relativ }\end{array}$ & $\begin{array}{l}\text { set arvot } \\
\text { Werte }\end{array}$ & Laatuero & $\begin{array}{l}\text { Alemman } \\
\text { Tiere nic }\end{array}$ & $\begin{array}{l}\text { ason yksilöiden } \\
\text { deven Niveaus }\end{array}$ & $\begin{array}{l}\text { Ylemmän } \\
\text { Tiere hö, }\end{array}$ & $\begin{array}{l}\text { ason yksilöiden } \\
\text { heren Niveaus }\end{array}$ \\
\hline 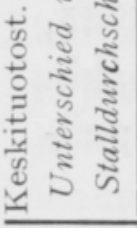 & 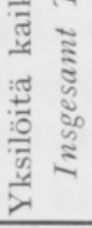 & 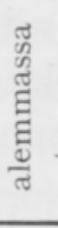 & 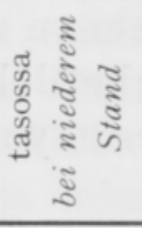 & 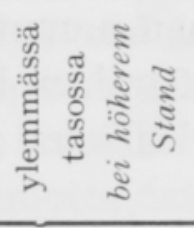 & $\begin{array}{c}\% \\
\text { Qualitäts- } \\
\text { unterschied }\end{array}$ & $\begin{array}{l}\text { hajonta } \\
\text { Streuung } \\
\text { s }\end{array}$ & $\begin{array}{c}\text { muuntelukerr. } \\
\text { Variations- } \\
\text { koeffizient } \\
\text { v }\end{array}$ & $\begin{array}{l}\text { hajonta } \\
\text { Streuung } \\
\text { s }\end{array}$ & $\begin{array}{c}\text { muntelukerr. } \\
\text { Variations- } \\
\text { koeffizient } \\
\text { v }\end{array}$ \\
\hline 399 & 2805 & & -66.6 & -100.9 & 17.1 & $595 \pm 11$ & $17.0 \pm 0.3$ & $624 \pm 12$ & $16.0 \pm 0.3$ \\
\hline 1017 & 2493 & & -26.4 & -110.8 & 16.6 & $581 \pm 12$ & $17.6 \pm 0.4$ & $677+14$ & $15.7 \pm 0.3$ \\
\hline 2048 & 314 & & +22.2 & -67.3 & 8.7 & $566 \pm 32$ & $18.8 \pm 1.1$ & $748 \pm 42$ & $14.8+0.9$ \\
\hline
\end{tabular}

1 Katso alaviittaa taulukossa 3.

1 Siehe Anm. Tab. 3. 
Taulukko 7. Karjojen väliset laatuerot maidon rasvapitoisuudessa (5-vuotiaiden jälkeläisten aineisto). Tabelle 7. Die Qualitätsunterschiede zwischen den Herden im Fettgehalt der Milch (Material 5jähriger Nachkommen).

\begin{tabular}{|c|c|c|c|c|c|c|}
\hline \multirow{2}{*}{$\begin{array}{c}\text { Karjoissa } \\
\text { lehmiä } \\
\text { Kühe in den } \\
\text { Herden }\end{array}$} & \multirow{2}{*}{$\begin{array}{c}\text { Eläinten } \\
\text { luku } \\
\text { Anzahl der } \\
\text { Tiere }\end{array}$} & \multicolumn{2}{|c|}{$\begin{array}{l}\text { Keskirasvaprosentit } \\
\text { Mittleres Fettprozent }{ }^{1}\end{array}$} & \multicolumn{2}{|c|}{$\begin{array}{c}\text { Suhteelliset arvot } \\
\text { Relative Werte }\end{array}$} & \multirow{2}{*}{$\begin{array}{c}\text { Laatuero } \\
\text { Qualitäts- } \\
\text { unterschied } \\
\%\end{array}$} \\
\hline & & $\begin{array}{c}\text { alemmassa } \\
\text { tasossa } \\
\text { bei niederem } \\
\text { Stand }\end{array}$ & $\begin{array}{c}\text { ylemmässä } \\
\text { tasossa } \\
\text { bei höherem } \\
\text { Stand }\end{array}$ & $\begin{array}{l}\text { alemmassa } \\
\text { tasossa } \\
\text { bei niederem } \\
\text { Stand }\end{array}$ & $\begin{array}{c}\text { ylemmässä } \\
\text { tasossa } \\
\text { bei höherem } \\
\text { Stand }\end{array}$ & \\
\hline-9 & 3962 & 4.091 & 4.372 & +0.169 & +0.128 & 29.2 \\
\hline $10-19$ & 478 & 4.024 & 4.339 & +0.160 & +0.121 & 24.8 \\
\hline \multirow[t]{2}{*}{20} & 223 & 4.104 & 4.350 & +0.180 & +0.194 & - \\
\hline & 4663 & $\begin{array}{r}4.185 \pm \\
0.005\end{array}$ & $\begin{array}{r}4.467 \pm \\
0.005\end{array}$ & $\begin{array}{r}+0.169 \pm \\
0.006\end{array}$ & $\begin{array}{r}+0.131 \pm \\
0.007\end{array}$ & 26.5 \\
\hline
\end{tabular}

näet $52,5,52.8$ ja 56.7 , joten näyttää siltä, että keskituotoserojen suuruudella ei ole vaikutusta laatueron osuuteen.

Taulukkoon 6 on laskettu myös yksilöiden suhteellisten erojen hajonnat ja muuntelukertoimet sekä alemman että ylemmän tason karjoissa. Luvuista havaitaan kilomääräisinä erotuksina ilmaistujen suhteellisten arvojen hajonnan selvästi suurenevan keskituotostason noustessa. Tässä suhteessa tulos poikkeaa Korkmanin (7) laskemista, hän kun ei ole havainnut hajonnan arvon muuttuvan tuotostason mukana. Mainittu tutkija tuleekin saamiinsa tuloksiin nojautuen päätelmään, että kilomääräisinä erotuksina ilmaistut suhteelliset arvot sopivat paremmin kuin prosenttiset yksilön perinnöllisen taipumuksen osoittajiksi. Taulukon 6 luvuista saa kuitenkin toisen käsityksen, koska hajonta näyttää suurenevan tuotostason noustessa. Sen sijaan muuntelukertoimien erot eri tasoissa eivät ole selviä, joskin suunta näyttää johdonmukaisesti olevan aleneva keskituotostason noustessa. Koska muuntelukerroin osoittaa tässä tapauksessa myös prosenttisten suhteellisten tuotosten hajonnan kehitystä, näyttäisi päinvastoin siltä, että prosenttisten arvojen pitäisi soveltua parhaiten yksilöiden laadun osoittamiseen. Tätä käsitystä puoltaa vielä se, että jos kerran keskituotos osittainkin osoittaa myös karjojen laadullisia eroja, pitäisi yksilöiden laadullisen muuntelun pienetä keskituotostason noustessa. Jos muuntelu lasketaan prosenttisista arvoista, näin näyttääkin käyvän, joten niitä senkin perusteella voitaisiin pitää sopivimpina. Edellä saadut tulokset karjojen laadullisten erojen suuruudesta viittaavat siihen, että karjojen tuotostason ei voida odottaa paljoakaan vaikuttavan yksilöiden muunteluun. Siitä syystä ei ole varmaa vaikkakin kyllä todennäköistä, että prosenttisia suhteellisia arvoja voitaisiin pitää kilomääräisiä erotuksia parempina. Ero on joka tapauksessa sangen pieni ja luultavasti käytännössä merkityksetön. Koska kilomääräiset erotukset ovat paitsi helpommin laskettavia ja käsiteltäviä myös epäilemättä useimmille helpommin tajut- 
tavia, päädytään tuonnempana puoltamaan kilomääräisten erotusten käytäntöön ottamista suhteellisina tuotoslukuina.

\section{Karjojen laatierot maidon rasvapitoisuuteen nähden.}

Vaikka tutkimuksen päätarkoituksena on ollutkin laatuerojen selvittäminen karjojen maidontuotantotaipumuksessa, suoritettiin vastaavanlaisia vertailuja myös keskirasvaprosentteihin nähden. Vertailuun saatavien eläinten löytäminen oli kuitenkin vaikeampaa kuin maidontuotantotaipumuksen eroja arvioitaessa, koska niiden karjojen keskirasvaprosentit, joissa oli saman sonnin jälkeläisiä, poikkesivat yleensä vähän toisistaan. Kun pienimpänä keskituotoserona mikä otettiin huomioon, oli $0.2 \%$,e1 5-vuotiaiden lehmien aineistossa pieniä karjoja lukuunottamatta saatu vertailuun riittävästi eläimiä. Tulokset eri ryhmissä ja koko aineistossa on esitetty taulukossa 7 .

Karjojen todelliset laadulliset erot ovat ilmeisiä, vaikkakin suurimpien karjojen ryhmässä sisarpuolten suhteellinen arvo oli suurempi ylemmässä tasossa kuin alemmassa, minkä vuoksi tulosta ei voitu laskea. Koska aineisto varsinkin suurten karjojen ryhmissä oli pieni, ei tuloksiin eri suurissa karjoissa voi kiinnittää paljon huomiota. Se viittaa joka tapauksessa siihen, että karjojen väliset laadulliset erot ovat maidon rasvapitoisuuteen nähden keskimäärin selvästi suuremmat kuin maidontuotantotaipumukseen nähden, mikä onkin luonnollista, koska maidon rasvapitoisuuden heritabiliteetti on yleisesti arvoitu suuremmaksi kuin maidon määrän. Varmemman kuvan saamiseksi laatuerojen osuudesta eri suurissa karjoissa tutkittiin vielä 7-11-vuotiaiden eläinten aineisto, ja tulokset nähdään taulukosta 8 .

Nyt saatu tulos näyttää viittaavan siihen, että karjojen suuruudella ei ole selvää vaikutusta karjojen välisiin laatueroihin, joskin suuremmassa aineistossa kehitys näyttää saman kaltaiselta kuin edellä maidon keskituotoksia tarkasteltaessa. Erot eivät ainakaan ole niin suuret ja selvät, että niihin olisi syytä käytännössä

Taulukko 8. Karjojen väliset laatuerot maidon rasvapitoisuudessa (7-11-vuotiaiden jälkeläisten aineisto). Tabelle 8. Die Qualitätsunterschiede zwischen den Herden im Fettgehalt der Milch (Material 7 - 11jähriger Nachkommen).

\begin{tabular}{|c|c|c|c|c|c|c|}
\hline \multirow{2}{*}{$\begin{array}{c}\text { Karjoissa } \\
\text { lehmiä } \\
\text { Kühe in den } \\
\text { Herden }\end{array}$} & \multirow{2}{*}{$\begin{array}{c}\text { Eläinten } \\
\text { luku } \\
\text { Anzahl der } \\
\text { Tiere }\end{array}$} & \multicolumn{2}{|c|}{$\begin{array}{l}\text { Keskirasvaprosentit } \\
\text { Mittleres Fettprozent }\end{array}$} & \multicolumn{2}{|c|}{$\begin{array}{c}\text { Suhteelliset arvot } \\
\text { Relative Werte }\end{array}$} & \multirow{2}{*}{$\begin{array}{c}\text { Laatuero } \\
\text { Qualitäts- } \\
\text { unterschied } \\
\%\end{array}$} \\
\hline & & $\begin{array}{c}\text { alemmassa } \\
\text { tasossa } \\
\text { bei niederem } \\
\text { Stand }\end{array}$ & $\begin{array}{c}\text { ylemmässä } \\
\text { tasossa } \\
\text { bei höherem } \\
\text { Stand }\end{array}$ & $\begin{array}{l}\text { alemmassa } \\
\text { tasossa } \\
\text { bei niederem } \\
\text { Stand }\end{array}$ & $\begin{array}{c}\text { ylemmässä } \\
\text { tasossa } \\
\text { bei höherem } \\
\text { Stand }\end{array}$ & \\
\hline-9 & 7745 & 4.089 & 4.394 & 0.095 & c. 061 & 22.3 \\
\hline $10-19$ & 3512 & 4.097 & 4.325 & 0.090 & 0.054 & 31.6 \\
\hline $20-39$ & 916 & 4141 & 4.358 & 0.080 & 0.023 & 52.5 \\
\hline $40-$ & 607 & 4.157 & 4.285 & 0.094 & 0.084 & 15.6 \\
\hline & 12780 & 4.098 & 4.367 & 0.093 & 0.057 & 26.7 \\
\hline
\end{tabular}


Taulukko 9. Karjojen laatuerojen riippuvuus keskirasvaprosentin erojen suuruudesta.

Tabelle 9. Die Abhängigkeit der Qualitätsunterschiede der Herden von der Grösse der Unterschiede des mittleven Fettprozents.

\begin{tabular}{|c|c|c|c|c|c|c|}
\hline \multirow{2}{*}{$\begin{array}{c}\text { Keskirasva- } \\
\text { prosenttien } \\
\text { ero } \\
\text { Unterschied } \\
\text { im mittleren } \\
\text { Fettprozent }\end{array}$} & \multirow[b]{2}{*}{$\begin{array}{c}\text { Yksilöitä } \\
\text { Tieve }\end{array}$} & \multicolumn{2}{|c|}{$\begin{array}{l}\text { Keskirasvaprosentit } \\
\text { Mittleres Fettprozent }\end{array}$} & \multicolumn{2}{|c|}{$\begin{array}{c}\text { Suhteelliset arvot } \\
\text { Relative Werte }\end{array}$} & \multirow{2}{*}{$\begin{array}{c}\text { Laatuero } \\
\text { Qualitäts- } \\
\text { unterschies } \\
\%\end{array}$} \\
\hline & & $\begin{array}{l}\text { alemmassa } \\
\text { tasossa } \\
\text { bei niederem } \\
\text { Stand }\end{array}$ & $\begin{array}{l}\text { ylemmässä } \\
\text { tasossa } \\
\text { bei höherem } \\
\text { Stand }\end{array}$ & $\begin{array}{l}\text { alemmassa } \\
\text { tasossa } \\
\text { bei niederem } \\
\text { Stand }\end{array}$ & $\begin{array}{l}\text { ylemmässä } \\
\text { tasossa } \\
\text { bei höherem } \\
\text { Stand }\end{array}$ & \\
\hline 0.157 & 2522 & 4.231 & 4.388 & +0.159 & +0.149 & 13.0 \\
\hline 0.334 & 1351 & 4.164 & 4.498 & +0.174 & +0.126 & 28.8 \\
\hline 0.526 & 531 & 4.112 & 4.638 & +0.197 & +0.118 & 30.3 \\
\hline 0.708 & 180 & 4.042 & 4.750 & +0.173 & +0.119 & 43.5 \\
\hline 0.886 & 60 & 4.021 & 4.907 & +0.179 & -0.100 & 62.9 \\
\hline 1.206 & 19 & 3.967 & 5.171 & +0.100 & +0.129 & - \\
\hline
\end{tabular}

kiinnittää huomiota. Tulos on sopusoinnussa sen kanssa, että eläinten rasvaprosentin muuntelukin oli yhtä suuri kaikissa karjaryhmissä. Sen sijaan näyttää oudolta, että yhteisten sonnien käyttö ei ole ainakaan yhtä selvästi tasoittanut laatueroja pienissä karjoissa niin kuin maidontuotantotaipumukseen nähden ilmeisesti oli tapahtunut. Selitys lienee siinä, että sonnien valinnassa ja yleensäkin siitosvalinnassa on rasvaprosenttiin kiinnitetty varsin vähän huomiota, niinkuin VAINIKAINEN $(13,14)$ ja LoNkA ovat todenneet, ja jota käsitystä myös omat tutkimukseni (16) tukevat. Näin ollen suurissakaan karjoissa ei ole tapahtunut yleensä mainittavaa laadullista erilaistumista. Toisaalta rasvaprosentin voimakas periytyvyys ja valinnan helppo suoritus on myös pienissä karjoissa tehnyt mahdolliseksi sonneihin ja lehmiin kohdistuneen valinnan tasapainon, joten ei selvää yhdenmukaistumistakaan ole havaittavissa.

Keskirasvaprosenttien eron suuruuden vaikutus tuloksiin nähdään taulukosta 9.

Karjojen laatueron osuus kokonaiserosta näyttää tämän mukaan riippuvan melko selvästi siitä, kuinka suuri on keskirasvaprosenttien ero. Mitä suurempi on ero ollut, sitä suurempi on myös laadun osuus kokonaiserosta. Erästämänkaltaisen vaihtelun selitys lienee etsittävissä m.m. Hammondin (3) ja Dinkhauserin (2) esittämästä käsityksestä, että erityisesti alhainen rasvaprosentti periytyy osittain vallitsevasti. Tähän viittaa saadussa tuloksessa se, että vaikka alemmassa tasossa olevat jälkeläiset poikkeavatkin eri ryhmissä karjan keskitasosta keskimäärin saman verran, ovat niiden sisarpuolet ylemmässä tasossa karjan muihin eläimiin verrattuna yleensä sitä heikompia, mitä suurempi on karjan keskimääräinen rasvaprosentti. Laadun osuuden kasvu suuremmissa eroluokissa olisi sen mukaisesti ainakin osaksi näennäistä. Myös voi laadun suurempi osuus keskituotoseroista silloin, kun erot ovat suuret, johtua yksinkertaisesti siitä, että karjojen hyvin korkeat keskirasvaprosentit on saavutettu pääasiassa siitosvalinnan tietä samalla kun tuotannon edellytykset 
Taulukko 10. Saman sonnin jälkeläisten asema rasvaprosentiltaan eritasoisissa karjoissa.

Tabelle 10. Die Stellung der Nachkommen eines und desselben Bullen in Herden von verschiedenem Fettprozent.

\begin{tabular}{|c|c|c|c|c|c|c|}
\hline \multicolumn{2}{|c|}{$\begin{array}{l}\text { Keskirasvaprosentti } \\
\text { Mittleres Fettprozent }\end{array}$} & \multirow{2}{*}{$\begin{array}{l}\text { Yksilöitä } \\
\text { yhteensä } \\
\text { Insgesamt } \\
\text { Tiere }\end{array}$} & \multirow{2}{*}{$\begin{array}{l}\text { Keskirasva- } \\
\text { prosenttien } \\
\text { ero } \\
\text { Unterschied } \\
\text { im mittleren } \\
\text { Fettprozent }\end{array}$} & \multicolumn{2}{|c|}{$\begin{array}{c}\text { Suhteelliset arvot } \\
\text { Relative Werte }\end{array}$} & \multirow{2}{*}{$\begin{array}{c}\text { Karjojer } \\
\text { laatuerc } \\
\% \\
\text { Qualitäts } \\
\text { unterschic } \\
\text { der Herde } \\
\%\end{array}$} \\
\hline $\begin{array}{l}\text { alemmassa } \\
\text { tasossa } \\
\text { bei niederem } \\
\text { Stand }\end{array}$ & $\begin{array}{c}\text { ylemmässä } \\
\text { tasossa } \\
\text { bei höherem } \\
\text { Stand }\end{array}$ & & & $\begin{array}{c}\text { alemmassa } \\
\text { tasossa } \\
\text { bei niederem } \\
\text { Stand }\end{array}$ & $\begin{array}{c}\text { ylemmässä } \\
\text { tasossa } \\
\text { bei höherem } \\
\text { Stand }\end{array}$ & \\
\hline 3.6 & $3.7<$ & 157 & 0.542 & 0.070 & 0.141 & - \\
\hline 3.8 & $3.9<$ & 813 & 0.416 & 0.153 & 0.102 & 24.5 \\
\hline 4.0 & $4.1<$ & 1313 & 0.321 & 0.161 & 0.127 & 21.5 \\
\hline 4.2 & $4.3<$ & 1142 & 0.292 & 0.189 & 0.146 & 29.5 \\
\hline 4.4 & $4.5<$ & 435 & 0.263 & 0.187 & 0.141 & 34.4 \\
\hline$<4.3$ & 4.4 & 1259 & 0.319 & 0.155 & 0.135 & 12.6 \\
\hline$<4.5$ & 4.6 & 853 & 0.388 & 0.197 & 0.131 & 33.8 \\
\hline$<4.7$ & 4.8 & 359 & 0.525 & 0.215 & 0.043 & 65.6 \\
\hline$<4.9$ & 5.0 & 63 & 0.688 & 0.266 & 0.040 & 54.1 \\
\hline$<5.1$ & 5.2 & 54 & 0.861 & 0.094 & 0.200 & - \\
\hline
\end{tabular}

rasvanmuodostuksen kannalta ovat maidon rasvapitoisuudesta riippumatta verraten tasaiset. Tämä mahdollisuus puoltaa maidon rasvapitoisuuden kehittämiseen tähtäävän siitosvalinnan perustamista rasvaprosentteihin sellaisenaan.

Mahdollinen vallintasuhde rasvaprosentin periytymisessä saattaa näin ollen vaikuttaa laatuerojen keskimääräiseen prosenttiin. Vallitsevien geenien osuus lienee kuitenkin suhteellisen pieni, joten niiden vaikutus tuntunee keskiarvossa vähän. Toisaalta on vallitsevia geenejä myös emillä, ja on luultavaa, että niitä on karjan lehmillä sitä enemmän, mitä alhaisempi on karjan keskirasvaprosentti tai, jos on niin, kuten Dinkhauser olettaa, että rasvaprosentin molemmat äärimmäiset arvot vallitsevat, sitä enemmän mitä alhaisempi tai korkeampi on karjan keskirasvaprosentti. Tämän seikan mahdollisen vaikutuksen toteamiseksi verrattiin saman sonnin jälkeläisten asemaa toisaalta sekä korkea- että matalaprosenttisissa karjoissa ja näitä alemmassa tai ylemmässä tasossa. Tulokset nähdään taulukosta 10 .

Jos vallitsevia geenejä on lehmillä, pitäisi jälkeläisten hyvin alhaisessa samoinkuin myös hyvin korkeassa tasossa poiketa vähiten karjojensa keskitasosta. Näin näyttääkin suurin piirtein tapahtuneen. Tulos ei tietenkään voi olla selvä sen vuoksi, että samanaikaisesti vaikuttavat vallitsevat geenit sekä emien että isien kautta. Lisäksi tuntuu tämä eri tahoilta tuleva vaikutus laatueroprosenteissa eri suuntaisena, joten asia on perusteellisemmin tutkittava toisia teitä. On myös mahdollista, että edellä esitettyihin tuloksiin on voinut olla vaikuttamassa muitakin tekijöitä, mm. emien valinta, joten mitään selviä johtopäätöksiä ei niistä voi tehdä. On vain syytä todeta, että vallintasuhteenmukaisella periytymisellä saattaa olla vaikutusta tuloksiin. Koska laatuerojen osuus keskirasvaprosenttien eroissa on ilmeisesti keskimäärin niin suuri, että rasvaprosentit sellaisenaan johtavat varsin onnistuneeseen ja keski- 
Taulukko 11. Karjojen laatuerojen osuus eri suurissa karjoissa piirroksesta 1.

Tabelle 11. Der Anteil der Qualitätsunterschiede der Herden bei verschieden grossen Herden nach Figur 1.

\begin{tabular}{|c|c|c|}
\hline \multirow{2}{*}{$\begin{array}{l}\text { Karjassa lehmiä } \\
\text { Kühe in der Herde }\end{array}$} & \multicolumn{2}{|c|}{$\begin{array}{l}\text { Suhteellinen tuotos laskettu } \\
\text { Relative Leistung berechnet }\end{array}$} \\
\hline & $\begin{array}{l}\text { kilomääräisenä } \\
\text { erotuksena } \\
\text { als kg-Unterschied }\end{array}$ & $\begin{array}{l}\text { prosenttisena } \\
\text { arvona } \\
\text { als Prozentsatz }\end{array}$ \\
\hline-9 & $1 / 10$ & 0.07 \\
\hline $10-14$ & $1 / 20$ & 0.05 \\
\hline $15-19$ & $1 / 10$ & 0.07 \\
\hline $20-24$ & $1 / 5$ & 0.14 \\
\hline $25-29$ & $1 / 4$ & 0.20 \\
\hline $30-39$ & $1 / 3$ & 0.30 \\
\hline $40-49$ & $1 / 2$ & 0.40 \\
\hline $50-$ & $1 / 1$ & 0.70 \\
\hline
\end{tabular}

määrin onnistuneempaan siitosvalintaan kuin niiden suhteelliset arvot yksinomaisesti käytettyinä, kuten aikaisemmat tutkimukseni (16) osoittivat, voidaan, koska menetelmien yksinkertaisuudesta on käytännön työssä pidettävä kiinni, rasvaprosenttiin kohdistuva valinta perustaa tarkkailukirjanpidosta sellaisenaan saataviin rasvaprosenttilukuihin. Tätä menettelyä puoltaa jo edellä todettu taulukossta 9 ja 10 ilmenevä seikka, että suurissa keskituotoseroissa ja myös korkeassa keskituotostasossa näyttää laadun merkitys olevan keskimäärää suurempi.

\section{Tulosten soveltaminen siitoseläinten arvosteluun.}

Tutkimuksessa käytetyllä menettelytavalla on pyritty selvittämään sitä merkitystä, mikä siitoseläimiä arvosteltaessa on annettava yksilön suhteelliselle arvolle ja karjan keskituotokselle. On selvää, että yksilön aseman arvosteleminen koko rodun puitteissa voidaan perustaa parhaiten samanaikaisesti juuri yksilön suhteelliseen arvoon, joka ilmaisee yksilön aseman karjassaan, toisin sanoen sen aseman toisiin likipitäen samoissa olosuhteissa olleisiin eläimiin verrattuna, ja karjan keskituotokseen, joka osoittaa karjan aseman koko rodussa. Näin menetellään mm. silloin, kun yksilön siitosarvo pyritään osoittamaan heritabiliteettikertoimien avulla $(5,6)$. Laskelman perusmuodon osoittaa kaava: $\mathrm{P}=\mathrm{R}+\mathrm{h}_{\mathrm{K}}{ }_{\mathrm{K}}(\mathrm{K}-\mathrm{R})+\mathrm{h}^{2}(\mathrm{Y}-\mathrm{K})$, jossa $\mathrm{P}$ on yksilön perinnöllinen arvo, $\mathrm{R}$ rodun keskiarvo, $\mathrm{K}$ karjan keskiarvo ja Y yksilön ilmiasu, tuotos. Jos heritabiliteettikertoimet $\mathrm{h}^{2} \mathrm{ja} \mathrm{h}^{2}{ }_{\mathrm{K}}$ ovat oikeita, saadaan yksilöt näin epäilemättä oikeimpaan laadulliseen arvojärjestykseen, mihin ne ilman ruokintakokeita samoissa olosuhteessa voidaan saada. Heritabiliteettikertoimista on se hyöty, että sekä yksilön suhteelliselle arvolle että karjan keskituotokselle annetaan niitä käyttäen se keskinäinen paino, mikä niille yksilön tai karjan laadun ilmaisijoina kuuluu. Jos karjojen laatuerot on selvitetty tässä tutkimuksessa noudatettua menettelytapaa käyttäen, jolloin on itse asiassa laskettu suhteellisten arvojen 


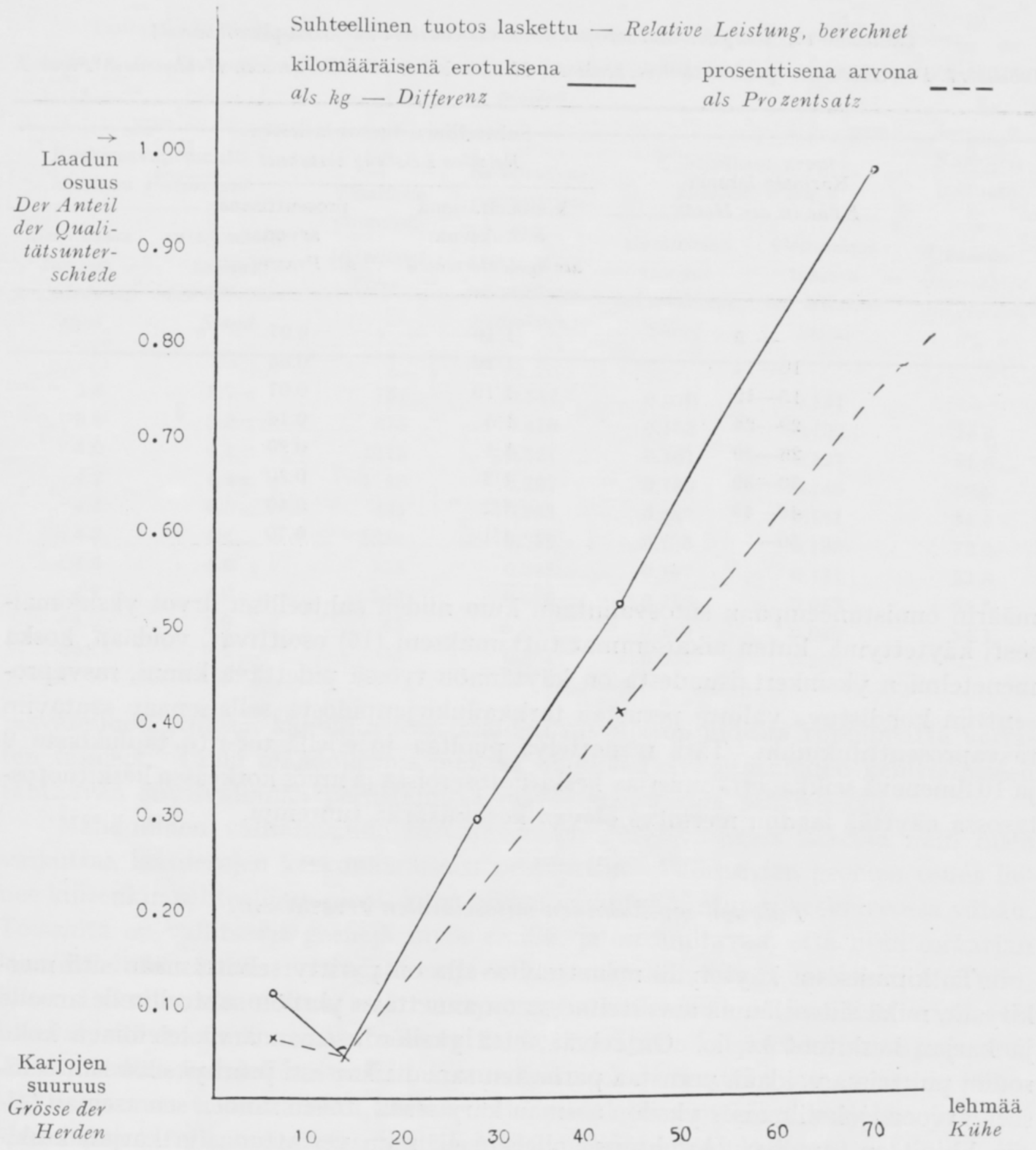

Piirros 1. Laatuerojen riippuvaisuus karjojen suuruudesta.

Figur 1. Die Abhängigkeit der Qualitätsunterschiede von der Grösse der Herde.

ja keskituotosten suhde laadullisten erojen osoittajina voidaan arvostelukaavaa vielä yksinkertaistaa ja jättää yksilön tuotosten heritabiliteettikerroin pois.

Siitoseläinten arvostelussa päästään parhaaseen tulokseen, jos eri suurissa karjoissa käytetään juuri niissä laskettuja arvoja. Koska aineistoa ei voitu ryhmitellä riittävän pieniin luokkiin laatuerojen ja karjojen koon keskinäisen riippuvuuden täsmälliseksi selvittämiseksi, on saatuihin tuloksiin nojautuen arvioitava tiettyjä keskilehmälukujen raja-arvoja vastaavat laadullisten erojen osuudet. Piirroksessa 1 on päädytty taulukon 11 lukuihin, jotka osoittavat laatuerojen osuuden keski- 
Taulukko 12. Lehmien jakaantuminen eri suuriin karjoihin.

Tabelle 12. Die Verteilung der Kühe auf verschieden grosse Herden.

Rotu

Karjassa lehmiä - Kühe in der Herde

Lehmät keskimäärin karjoista, joiden lehmäluku

Rasse $1-9 \quad 10-19 \quad 20-29 \quad 30-39 \quad 40-49 \quad 50-59 \quad 60-69 \quad 70-79 \quad 80-89 \quad 90-99 \quad 100-$

Kühe durchschnittl. von den Herden, deven Tierzahl

\begin{tabular}{|c|c|c|c|c|c|c|c|c|c|c|c|c|c|}
\hline $\begin{array}{l}\text { Suomen karja } \\
\text { Finnische Land- }\end{array}$ & $\begin{array}{l}\mathrm{kpl} \\
S t\end{array}$ & 3574 & 1901 & 367 & 135 & 37 & 9 & & 8 & 4 & & 19 & 11.0 \\
\hline herde & $\%$ & 59.0 & 31.4 & 6.1 & 2.2 & 0.6 & 0.2 & & 0.1 & 0.1 & & 0.3 & \\
\hline Ayrshire & $\begin{array}{l}\text { kpl } \\
S t\end{array}$ & 3030 & 2294 & 908 & 522 & 288 & 104 & 178 & 126 & 52 & 104 & 73 & 19.6 \\
\hline Ayrshive & $\%$ & 39.5 & 29.9 & 11.8 & 6.8 & 3.8 & 1.3 & 2.3 & 1.6 & 0.7 & 1.3 & 1.0 & \\
\hline
\end{tabular}

tuotosten kokonaiseroista eräissä karjojen suuruusluokissa silloin, kun yksilön laatu on arvosteltu suhteellisella arvolla.

Näitä laatuerojen osuuksia käyttäen on nyt mahdollista selvittää tietyn karjan todennäköinen laadullinen asema koko rodun keskiarvoon verrattuna. Jos karjan keskituotoksen (kt) poikkeama rodun keskiarvosta $(\mathrm{R})$ on $\triangle \mathrm{kt}$ ja karjan lehmälukua vastaava laadullisten erojen osuus on p, on karjan todennäköinen laadullinen poikkeama rodun keskiarvosta $\triangle \mathrm{kt} \times \mathrm{p}$. Tästä arvosta on kuitenkin sanottava, että se on karkea likiarvo, joka johtaa vain k e s k i m ä ä r i n oikeaan karjojen arvojärjestykseen. Sellaisenaan on siis p:llä vain tavanomainen keskiarvon merkitys, muttä eläinjoukkoihin, karjoihin, sovellettaessa se puolustaa paikkaansa silloin, kun parempaa arvostelutapaa ei ole olemassa. Jos siis yksilön todennäköinen asema koko rodussa halutaan arvioida, on suhteellisen arvon lisäksi otettava huomioon sen karjan todennäköinen poikkeama rodun keskiarvosta. Yksilöiden paras laskettavissa oleva siitosarvo, jota merkitään $\mathrm{S}_{1}$ :llä, olisi siten, kun $\Delta \mathrm{kt}=\mathrm{kt}-\mathrm{R}$

$$
\mathrm{S}_{1}=\mathrm{S}+\Delta \mathrm{kt} \cdot \mathrm{p} .
$$

Rodun yhteisen keskiarvon $\mathrm{R}$ käyttö suosii taloudelliselta ja yhteiskunnalliselta sijainniltaan edullisemmissa asemissa olevia seutuja. Olisi sen vuoksi oikeampaa, että rodun keskiarvo korvattaisiin luonnollisten maatalousalueiden, esim. maanviljelysseura-alueiden keskiarvoilla, koska voidaan pitää todennäköisenä, että laadultaan eri alueiden karja-aines on likipitäen samanarvoista. Lisäksi karja-aineksen mukautuneisuus tiettyihin oloihin puoltaa niissä oloissa kehittyneen siitoseläinaineksen ensisijaista käyttöä. Näin sovellettuna edellä esitetty arvostelukaava soveltuisi käytettäväksi mm. kantakirjatyössä. Tietysti on mahdollis'a, jos alueellista jakoa pidetään liian monimutkaisena, suorittaa eläinten luokitus koko valtakunnan alueen yhteisiä keskiarvoja käyttäen. Sellainenkin menettely vähentää jo varsin tuntuvasti niitä karkeita virheitä, jotka johtuvat yksinomaan absoluuttiarvoihin perustuvasta luokituksesta. Koska sonneille tähän mennessä lasketuissa jälkeläisarvostelun tuloksissa ei ole kiinnitetty huomiota karjojen suuruuteen, onkin 
niiden luokituksessa käytettävä ainakin laatuerojen osuuteen p:hen nähden koko rodun keskiarvoa. Edellä saatujen tulosten mukaan tulee sen laskemisen perustua rodun yksilöiden jakaantumiseen eri suuriin karjoihin.

Taulukosta 12 nähdään erään koko valtakunnan tarkkailukarjakantaa melko hyvin edustavan lehmäaineksen jakaantuminen karjojensa suuruuden mukaan. Tekijä on aikaisemmassa tutkimuksessa (16) esittänyt yhtälön

$$
\mathrm{r}_{\mathrm{M}: \mathrm{S}} \approx \frac{\mathrm{r}_{\mathrm{S}: \mathrm{S}}+\mathrm{r}_{\mathrm{kt}: \mathrm{S}}}{\sqrt{2}},
$$

joka osoittaa absoluuttisen ja suhteellisen tuotoksen sekä karjan keskituotoksen keskinäisen likimääräisen suhteen yksilön laadun määräytymisessä, kun sitä arvostellaan jälkeläisten suhteellisten arvojen perusteella. Siitä voidaan todeta, että jos keskituotosten merkitys laatuerojen osoittajana on n. $40 \%$ tai enemmän suhteellisten arvojen merkitykseen verrattuna, päästään absoluuttisella arvostelulla yhtä onnistuneeseen tai jopa parempaan tulokseen kuin suhteellisella Mutta tämän rajan yläpuolellakin voidaan valintaa absoluuttiseen arvosteluun verrattuna varmistaa perustamalla se oikeata painotusta käyttäen yksilöiden suhteellisiin arvoihin ja karjojen keskituotoksiin.

On huomattava, että taulukossa esitetyt keskiluvut eivät ole karjojen keskimääräisiä keskilehmälukuja vaan ne osoittavat, että Suomen karjan lehmät ovat keskimäärin 11 ja ayrshirelehmät keskimäärin n. 20 lehmän karjoista. Koska aineistosta puuttuvat eräitä pienikarjaisia seutuja edustavat eläimet, ovat keskiarvot hivenen verran liian suuria. Jakaantuminen on kuitenkin hyvin yhdenmukainen karjantarkkailukomitean koko tarkkailukarja-aineistosta vuodelta 1949 -50 maataloushallituksen tilastotoimiston laskelmien pohjalta kokoaman tilaston kanssa, jonka mukaan eläimet jakaantuivat eri ryhmiin seuraavasti:

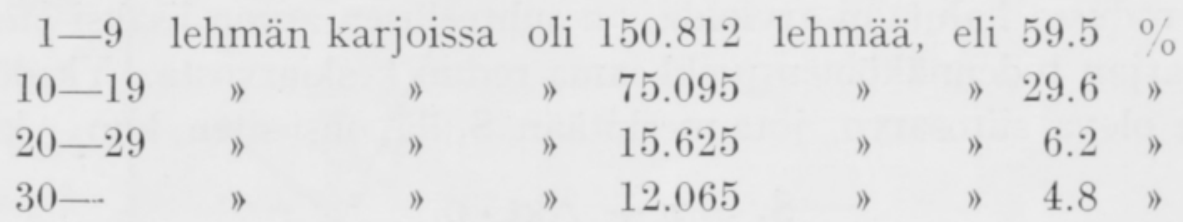

Kun nyt esitettyihin lukuihin nojautuen lasketaan rotujen keskiarvot, päädytään siihen, että Suomen karjalla on karjojen keskimääräinen laatuero $12 \%$ ja ayrshirerodulla $23 \%$ keskituotosten kokonaiseroista. Kun otetaan huomioon, mitä sanottiin taulukon 12 aineiston edustavuudesta, saadaan p:n arvoksi Suomen karjalla $1 / 9$ ja ayrshirerodulla $1 / 5$, jota lukua tekijä on aikaisemmin juuri ayrshirekarjaaineistolla suoritettujen tutkimusten perusteella suositellut yleisesti käytettäväksi.

Suomen karjalle keskilukua laskettaessa on nojauduttu ayrshireaineistolla suoritettuihin tutkimuksiin ja Suomen karjan lehmien jakaantumiseen erisuuriin karjoihin. Eri rotuisten yksilöiden käyttäytyminen on siten oletettu keskimäärin samankaltaiseksi. Koska ei ole mitään syytä epäillä menettelyn oikeutusta - molemmat rotummehan ovat osoittautuneet useimmilta muiltakin taipumuksiltaan varsin yhdenmukaisiksi -, on laskemistapa puolustettavissa varsinkin, kun näin voidaan välttyä melko suurien töiden kaksinkertaiselta suorittamiselta. 
On syytä vielä huomauttaa, että nyt esitetyt luvut eivät kenties ole täysin oikeita sonnien tuotantoarvoja laskettaessa. Koska sonnit arvostellaan useimmiten useita karjoista saatujen tulosten keskiarvoina on todennäköistä, että p:n arvot sonnien tuotantoarvoaineistossa muodostuvat nyt esitettyjä jonkin verran pienemmiksi, tai tytärarvoja käytettäessä ehkä suuremmiksikin. Erot lienevät kuitenkin siksi pienet, että esitettyjä lukuja voidaan soveltaa sonnienkin luokitukseen, kunnes uudet tarkistetut luvut on saatu lasketuiksi.

Jos on kysymys, kuten siitosvalinnassa tavallisesti, vieraan karjan yksilön todennäköisestä asemasta tietyssä karjassa, on ensiksi selvitettävä karjojen keskinäinen suhde. Se todetaan erotuksen $\triangle \mathrm{kt} \times \mathrm{p}-\Delta \mathrm{kt} \times \mathrm{p}_{1}$ avulla. Siinä on $\triangle \mathrm{tk}_{1} \times \mathrm{p}_{1}$ siitoseläintä hankkivan karjan todennäköinen poikkeama rodun keskitasosta ja $\triangle \mathrm{kt} \times \mathrm{p}$ sen karjan poikkeama, josta siitoseläin aiotaan hankkia. Erotus lisättynä yksilön suhteelliseen arvoon osoittaa sen todennäköisen aseman uudessa karjassa. Jos vertailtavat karjat kuuluvat samaan suurusluokkaan, on vertailu helpompi, koska todennäköinen laadullinen ero voidaan laskea silloin yksinkertaisesti vain karjojen keskituotosten erotuksesta kertomalla se p:n arvolla.

Tullaanko valinnan tukena käyttämään suhteellisten arvojen täydennyksenä koko rodun keskiarvojen perusteella laskettuja karjojen laadullisia eroja tai vastaavia eri suuruusluokkien arviolukuja riippuu menetelmän käytännöllisistä toteuttamismahdollisuuksista. Tärkeintä on, että luokituksen pohjan muodostavat suhteelliset arvot. Niihin verrattuna on karjojen laatuerojen huomioon ottaminen keskimäärin jo †oisarvoista, ja mitä pienempiä karjat ovat, sitä vähemmän keskituotoserot merkitsevät. Suhteellisiin arvoihin perustuvan yksilöiden arvojärjestyksen oikaisu karjojen laadullisilla eroilla epeilemättä varmistaa valintaa keskimäärin arvostellen, joskin yksityistapauksissa voi tarkistus, kuten keskiarvolukuihin perustuvat korjaukset yleensä, johtaa aivan virheelliseen, jopa suunnaltaan virheelliseen tulokseen. Esitettyä menettelyä karjojen laadullisten erojen huomioon ottamista ei voida siis pitää läheskään kysymyksen lopullisena ratkaisuna, mutta väliaikaisena parempien menetelmien korvikkeena sillä on arvoa varsinkin suurehkojen karjojen jalostusvalinnassa. Tutkimuksen tulokset, karjojen laadullisten erojen pienet osuudet karjojen kokonaiseroista, osoittavat, että täsmällisempien menettelytapojen löytäminen karjojen laatuerojen osoittajiksi olisi onnistuvan jalostustyön tärkeimpiä edellytyksiä ja siitä syystä tutkimuksen ensimmäisiä tehtäviä. Yksilöiden, ainakin todennäköisesti parhaiden, vertaamiseen tarkalleen samanlaisissa olosuhteissa olisi koetettava päästä nautakarjankin jalostuksessa. Sikatalouskoeaseman tulokset ovat sellaisen tarpeeellisuudesta vakuuttavana osoituksena.

Keskituotosten ja suhteellisten arvojen suhde 1/1 yli 50 lehmän karjojen ryhmässä merkitsee itse asiassa sitä, että absoluuttinen arvostelu johtaa samaan tulokseen kuin edellä selostettu suhteellisten arvojen ja keskituotoslukujen yhteiskäyttö. Näin ollen näissä suurissa karjoissa voidaan myös siitoseläimiä karjasta toiseen vaihdettaessa arvostella yksilöt yksinkertaisesti absoluuttisia tuotoslukuja käyttäen. Jotta kuitenkin menettelytavat saataisiin yhdenmukaisiksi, olisi tällöinkin, ja varsinkin siitoseläimiä pienempiin karjoihin etsittäessä, syytä nojautua arvostelussa sekä suhteelliseen arvoon että keskituotoksiin. 
Vaikka aikaisemmin esitetyn mukaan prosenttisia suhteellisia arvoja voidaankin pitää tarkoituksenmukaisempina kuin kilomääräisiä erotuksia, on niiden käyttö yhdessä keskituotosten kanssa huomattavasti hankalampaa kuin kilomääräisten erotusten, jotka muutenkin lienevät useimmille karjanomistajille helpommin tajuttavissa. Kävisi myös liian monimutkaiseksi käyttää kahta rinnakkaista lukusarjaa saman tehtävän ratkaisemiseen, kun erot tuloksissa lienevät sangen pienet, eikä myöskään ole varmaa osoitusta kumpaisenkaan menetelmän paremmuudesta. Lisäksi on prosenttisten arvojen käyttö tutkimuksissa paljon vaikeampaa kuin kilomääräisten erotusten, koska ne eivät sovellu yhtä helposti ja täsmällisesti matemaattisiin jatko-operaatioihin. Näiden syiden nojalla onkin päädytty puoltamaan kilomääräisten erotusten käyttöä suhteellisina arvoina helposti laskettavina ja selvinä tunnuslukuina. Koska sonnien tuotantoarvoissa suhteelliset arvot on tähän asti aina ilmaistu yksinomaan prosenttilukuina, voidaan rotujen keskiarvoina käyttää niiden ohella p:n arvoina Suomen karjalla 0.10 ja ayrshirerodulla $0.15 .^{1}$ Sonnin arvo lasketaan silloin kaavasta:

$$
\mathrm{S}_{1}=\mathrm{S}+\frac{\Delta \mathrm{kt} \times 100}{\mathrm{R}} \times \mathrm{p}
$$

Nyt selostettu tutkimuksen tulosten soveltaminen käytäntöön koskee, kuten sanottu, vain eläinten maidontuotantotaipumuksen arvostelua. Rasvaprosentin jalostamisessa päästään tyydyttäviin tuloksiin ilmeisesti yksinkertaisimmin, kun arvostelu perustuu rasvaprosentteihin sellaisenaan.

\section{Lоррирӓ̈ӓelm $\ddot{a} t$}

Maito. Kun karjojen laadullisten erojen osuus keskituotosten kokonaiseroista arvioidaan saman sonnin eritasoisiin karjoihin jättämıen jälkeläisten aseman perusteella karjan muihin eläimiin verrattuna tullaan tulokseen, että laadun osuus riippuu vahvasti karjojen suuruudesta. Yleensä laadun osuus suurenee karjojen suuretessa, kuitenkin niin, että pienin arvo on saatu lähinnä pienimpien, 10-10 lehmän karjojen 1yhmässä (taulukot 2 ja 3). Hyvin suurissa karjoissa on karjojen keskituotoksille annettava sama merkitys kuin suhteellisille tuotoksille eläinten laatuerojen osoittajina, joten niissä voidaan yksilöiden arvostelu perustaa myös tuotosten absoluuttiarvoihin sellaisenaan.

Laskettaessa karjojen laadullisten erojen osuudelle koko rodun keskiarvoa on lähtökohtana pidettävä lehmien jakaantumista eri suuriin karjoihin. Keskiarvoksi saadaan siten ayrshirerodulle $1 / 5$ ja Suomen karjalle arviolta 1/9.

Keskituotoserojen suuruudella ei näytä olevan vaikutusta karjojen laadullisten erojen osuuteen (taulukko 6).

Koetettaessa selvittää syitä siihen, että karjojen laatuerot keskimäärin suurenevat karjojen suuretessa on arveltu, että pienissä karjoissa yhteisten sonnien käyttö

1 Vastaa myös aikaisemmin selostettua isien keskituotosten ja suhteellisten arvojen sekä poikien vuorosuhteiden 0.04 ja 0.27 suhdetta. 
on tasoittanut vertailtujen karjojen laadullisia eroja. Pienten karjojen ryhmiin on pääasiassa tullut karjoja, jotka ovat kuuluneet samoihin sonninpitoyhtymiin useissa tapauksissa ehkä jo kymmenien vuosien aikana. Suurissa karjoissa sen sijaan on sonnien valtaosa jättänyt jälkeläisiä vain yhteen karjaan (taulukko 4), ja yhteiset sonnit ovat niissä olleet satunnaisia poikkeustapauksia. Samalla kun yhteiset sonnit suurissa karjoissa eivät ole merkittävässä määrässä olleet tasoittamassa karjojen laadullisia eroja on karjoissa erilaisin perustein tapahtunut siitosvalinta johtanut niiden erilaistumiseen. Tämä kehitys on vielä tehostunut, kun karjoissa tapahtuvalla siitosvalinnalla on suurissa karjoissa ymmärrettävistä syistä suuremmat onnistumisen mahdollisuudet kuin pienissä. Toisaalta on laadullisten erojen osuudelle suurissa karjoissa saatu suurempi lukuarvo saattanut johtua myös siitä, että tuotannon ulkonaiset edellytykset ovat suurissa karjoissa olleet tasaisemmat kuin pienissä. Tähän viittaa se, että karjojen keskituotosten hajonnalle on saatu suurin lukuarvo pienimmissä karjoissa.

Jos yksilöiden suhteellisena tuotoksena käytetään kilomääräistä erotusta, suurenee yksilöiden hajonta tuotostason noustessa, mutta muuntelukerroin sen sijaan pienenee (taulukko 6). Tämä voisi viitata siihen, että prosenttisia suhteellisia arvoja olisi pidettävä kilomääräisiä eroja tarkoituksenmukaisempina. Erot lienevät kuitenkin niin pienet, että käytännöllisten seikkojen voidaan antaa ratkaista, kumpaa laskemismenetelmää käytetään.

Sekä maidon että rasvaprosentin suhteellisten arvojen vuorosuhde on ollut yhtä suuri kaikensuuruisissa karjoissa (taulukko 5). Sitä voitanee pitää osoituksena siitä, että suhteellisilla arvoilla on sama merkitys yksilön aseman osoittajina niin pienissä kuin suurissakin karjoissa. Koska suhteellisten maitotuotosten hajonta kuitenkin on pienissä karjoissa pienempi kuin suurissa, saavat hyvät eläimet niissä liian pieniä ja huonot liian suuria arvoja. Huonojen eläinten osalta, joista jälkeläisiä ei oteta, ei tällä seikalla ole merkitystä ja parhaimpiinkin nähden lienee tarkoituksenmukaista asettaa pienten karjojen yksilöille suuremmat vaatimukset, koska tulokset niissä lienevät jossakin määrin epävarmempia.

Maidon rasvapitoisuns. Karjojen laadulliset erot maidon rasvapitoisuuteen nähden eivät ole ainakaan selvästi riippuvaisia karjojen suuruudesta (taulukot 7 ja 8). Sen sijaan näyttää keskirasvaprosenttien eron suuruus vaikuttavan siten, että eron suuretessa laadun osuus kasvaa (taulukko 9). Myös rasvapitoisuuden noustessa näyttää laadun osuus lisääntyvän (taulukko 10). Tämän perusteella voidaan maidon rasvapitoisuuden jalostamisessa nojautua rasvaprosentteihin sellaisenaan, mitä menettelyä myös tekijän aikaisemmat tutkimukset puoltavat.

Rasvaprosentista saatuihin erilaisiin tuloksiin maidontuotantoon verrattuna on saattanut vaikuttaa rasvapitoisuuden huomattavasti yksinkertaisempi periytyminen samoin kuin vallitsevien geenien mahdollinen osuus rasvapitoisuuden välittäjinä.

Tulosten soveltaminen yksilön arvosteluun. Koska karjojen keskituotoserot perustuvat keskimäärin vain pieneksi osaksi laadullisiin eroihin, tulee maidontuotantotaipumuksen jalostuksessa valinnan nojautua ensisijassa yksilöiden suhteellisiin tuotoksiin. Kun keskituotosten suuremmuus kuitenkin viittaa myös karjan parem- 
paan laatuun, voidaan yksilöiden luokittelussa myös niiden karjojen keskituotoseroista ottaa huomioon se osa, mikä keskimäärin perustuu laatuun. Saman rodun puitteissa voidaan yksilöiden arvo yksinkertaisimmin saada yhtälöstä

$$
\mathrm{S}_{1}=\mathrm{S}+\Delta \mathrm{kt} \cdot \mathrm{p}
$$

jossa $\mathrm{S}_{1}$ on yksilön todennäköinen asema rodussa, $\mathrm{S}$ sen suhteellinen arvo karjassaan, $\triangle \mathrm{t}$ karjan poikkeama rodun keskiarvosta ja p laadun osuus keskituotoserosta. Siinä tapauksessa että p:n arvona käytetään rodun keskiarvoa, voidaan $\triangle \mathrm{kt}$ :n kohdalle merkitä myös karjojen keskituotosten erotus, jolloin $\mathrm{S}_{1}$ ilmaisee yksilön todennäköisen suhteellisen arvon toisessa karjassa. Oikeampaan tulokseen päästään kuitenkin, jos p:n arvo valitaan karjan suuruuden mukaan seuraavasti. Laadun osuus on ilmaistu murtolukuna, jos suhteellisena tuotoksena on käytetty kilomääräistä erotusta ja desimaalilukuna, jos se on laskettu prosenttisena arvona.

$\begin{array}{rrrr}\text { Lehmäluvun ollessa } & -9 & 1 / 10 & 0.07 \\ 10-14 & 1 / 20 & 0.05 \\ 15-19 & 1 / 10 & 0.07 \\ 20-24 & 1 / 5 & 0.14 \\ 25-29 & 1 / 4 & 0.20 \\ 30-39 & 1 / 3 & 0.30 \\ 40-49 & 1 / 2 & 0.40 \\ 50- & 1 / 1 & 0.70\end{array}$

$\triangle \mathrm{kt}: \mathrm{n}$ arvon laskemiseen voidaan tällöin käyttää joko koko rodun keskiarvoa tai mieluummin kunkin maatalousalueen, esimerkiksi maanviljelysseura-alueen keskiarvoa.

Prosenttisia suhteellisia tuotoksia käytettäessä on $\triangle \mathrm{kt}$ korvattava lausekkeella

$$
\frac{\Delta \mathrm{kt} \cdot 100}{\mathrm{R}} .
$$

\section{KIRJALLISUUSLUETTELO}

(1) Bonnier, G. 1946. The Sire Index. Acta Agriculturae Suecana 1, p. $321-334$.

(2) Dinkhauser, F. 1940. Untersuchungen über den Erbgang des Milchfettgehaltes beim Rinde. Zeitschr. f. Tierzüchtung u. Züchtungsbiologie, 46, p. 237-279.

(3) Hammond, J. 1952. Low Butterfart slightly dominant to High Butterfat. Abstract in The British Friesian Journal, 34, 2, p. 202.

(4) Hansen Larsen, L. og H. Wenzel Eskedal 1952. Fodring af Køər med høj Maelkeydelse. 260. beretning fra forsøgslaboratoriet.

(5) Johansson, I. 1951. Konferens i Utrecht angående avkommebedömningarnas tillämpning inom husdjursaveln. SRB Tidskrift 1951, 4, p. 4-10.

(6) Korkman, N. 1950. Bedömning av husdjurens avelsvärde. Kungl. Lantbruksakad. Tidskrift, 5 -6, p. 377 .

(7) —- 1953. Versuch einer vergleichenden Nachkommenschaftsuntersuchung von Bullen, die in Herden mit verschieden starken Fütterung wirken. Zeitschr. f. Tierzüchtung u. Züchtungsbiologie, 61, 4, p. 373-390. 
(8 LonkA, T. 1947. Valtion karjat jalostuksen tukena. Valt. maatalouskoet. tied., 209.

(9) v. Patow, C. 1930. Weitere Studien über die Vererbung der Milchleistung beim Rinde. Zeitschr. f. Züchtung B, 17, p. 3-159.

(10) PoIJärvi, I. 1953. Onko eri lehmäyksilöiden rehunkäyttökyky taloudellisesti merkitsevässä määrässä erilainen? Karjatalous 1953,2 , p. $46-50$.

(11) Robertson, A., And Asker, A. A. 1951. The genetic history and breed-structure of British Friesian cattle. Emp. Journ. Exp. agric., 19 p. 113-130.

(12) Skjervold, H. OG Syrstad, O. 1953. Vurdering og valg av avelsdyr. Buskap og avdrått 1953, 1, p. $40-44$.

(13) VAinikainen, V. 1931. Erilaisten kantakirjalehmien vasikoitten käytöstä itäsuomalaisissa karjoissa. Valt. maatalouskoet. julk. 36.

(14) —— 1934. Erilaisten kantakirjalehmien vasikoitten käytöstä länsisuomalaisissa ja Suomen Ayrshirekarjoissa. Ibid., 59.

(15) VARo, M. 1951. Koneellisesti lasketuista tuotantoarvoista. Suomen Ayrshirelehti, 1, p. 3-4.

(16) —- 1952. Tutkimuksia karjanjalostuksen tehostamismahdollisuuksista erityisesti sonnien valintaa silmälläpitäen. Acta Agralia Fennica, 77.

(17) — - 1953. Siitoseläinten suhteellisesta arvostelusta. Karjatalous, 11, p. 315-320.

\section{REFERAT:}

ÜBER DIE QUALITATIVEN UNTERSCHIEDE ZWISCHEN HERDEN

Mikko Varo

Landwirtschaftliche Versuchsanstalt, Abteilung für Haustierzüchtung, Tikkurila

In der Untersuchung sind durch Vergleich der Stellung der von einem und demselben Bullen in verschiedenen Herden hiterlassenen Nachkommen die durchschnittlichen qualitativen Unterschiede der Herden zu klären versucht worden. Dabei ist angenommen worden, dass in einer qualitativ besseren Herde die Nachkommen eines und desselben Bullen im Vergleich zu den übrigen Kühen der Herde ungünstiger gestanden haben als in einer schwächeren Herde, d.h. die Nachkommen haben in einer besseren Herde durchschnittlich einen geringeren relativen Wert angenommen als in einer schlechteren. Infolge der Vererbung in Zwischenform ist vorausgesetzt worden, dass die Grösse des Qualitätsunterschiedes doppelt so gross wie der Unterschied der relativen Werte der Nachkommengruppen sei. Die Vergleiche sind in Herden von verschiedenem mittleren Leistungsstand ausgeführt worden, und da der prozentuale Anteil des auf die angegebene Weise berechneten Qualitätsunterschiedes von den gesamten mittleren Leistungsunterschieden berechnet worden ist, haben sich Zahlen ergeben, die erkennen lassen, inwieweit sich die Unterschiede in den mittleren Leistungen der Herden auf die verschiedene Beschaffenheit der Tiere gründen. Da die Berechnung sich auf die relativen Werte der Nachkommengruppen gründet, erweisen die erhaltenen Prozentsätze auch, welcher Wert den mittleren Leistungen der Herde, im Vergleich mit den relativen Leistungen, als Indikatoren der Beschaffenheit der Tiere beizulegen ist.

Als relativer Wert ist der in $\mathrm{kg}$ angegebene Unterschied der individuellen Leistung gegenüber der mittleren Leistung der Herde benutzt worden. Auch die den prozentualen relativen Werten entsprechenden Ergebnisse sind zur Berechnung gelangt. Als Material haben 5jährige Ayrshirekühe aus dem Kontrolljahr 1949-50 gedient, woneben man zur Bestätigung der Ergebnisse mit 7-11jährigen Tieren Wiederholungsberechnungen ausgeführt hat. Entsprechende Vergleiche wurden auch in bezug auf den Fettgehalt der Milch angestellt.

\section{Ergebnisse}

Als das Material der 5jährigen Kühe als Gesamtheit betrachtet wurde, schienen die Qualitätsunterschiede durchschnittlich $15.3 \%$ (Tabelle 1) von den Gesamtunterschieden der mittleren Leistungen der 
Herden auszumachen. Bei Anwendung der prozentualen relativen Werte war der Anteil der Qualität noch geringer. Das erhaltene Ergebnis stimmt als solches recht gut mit den von BonniER (1), JoHANsSON (5), Robertson und ASker (11), SkJerwold (12) und Korkman (7) angegebenen Zahlenwerten in dem Sinne überein, dass die Qualität einen verhältnismässig geringen Anteil am Entstehen der Unterschiede in den mittleren Leistungen der Herden zu haben scheint. Als aber die Ergebnisse bei verschieden grossen Herden miteinander verglichen wurden, stellten sich bei beiden Materialien (Tabelle 2 und 3 ) für den Anteil der qualitativen Unterschiede bei den verschiedenen Grössengruppen der Herden sehr verschiedene Werte heraus. Die Entwicklung der Werte war insofern recht gleichmässig, als der geringste Wert $(6.2$ und $5.2 \%)$ sich bei Herden von 10 - 19 Kühen ergab, während die Qualitätsunterschiede im allgemeinen mit steigender Tierzahl der Herden zunahmen. Dass die Qualitätsunterschiede in der Gruppe der allerkleinsten Herden nicht am geringsten sind, mag als Beweis dessen gelten, dass die erhaltenen Unterschiede nicht einzig auf die Ungenauigkeit der bei kleinen Herden berechneten relativen Leistungen zurückzuführen sind. Auf der Suche nach den Ursachen hat sich die Aufmerksamkeit derverschiedenen Anwendung der Bullen in verschiedenen grossen Herden zugewandt. Zu der Gruppe der kleinen Herden gehören in erster Linie Herden, in denen schon lange Zeit gemeinsame Genossenschaftsbullen eingesetzt worden sind, während dagegen bei grossen Herden deren eigene Bullen nur selten und gelegentlich anderswo Nachkommen hinterlassen haben. Die gemeinsamen Bullen haben somit die qualitativen Unterschiede zwischen den kleinen Herden ausgeglichen. Da zugleich die Möglichkeiten der in den Herden vorzunehmenden Auslese bei grossen Herden grösser sind als bei kleinen, in denen das Beurteilen der Individuen unsicherer wie auch das Erhalten eines Nachkommen von einem Tier erwünschter Beschaffenheit schwieriger ist, ist es recht natürlich, dass für das Entstehen von Qualitätsunterschieden auf dem Wege der Veredlung bei grossen Herden die besten Möglichkeiten bestanden haben.

Doch gibt es auch eine solche Möglichkeit, dass sich der verschiedene Anteil der Qualitätsunterschiede bei ungleich grossen Herden zum Teil auch auf die gleichmässigeren Erzeugungsmöglichkeiten grosser Herden, vor allem auf eine gleichmässigere Fütterung gründet. Es ist nicht möglich gewesen, diesen Umstand auf Grund des verfügbaren Materials zu untersuchen. Die Streuungen in den mittleren Leistungen der Herden deuten jedoch auf diese Möglichkeit hin, denn obgleich nach den Ergebnissen die Qualitätsunterschiede zwischen grossen Herden stärker sind als zwischen kleinen, belaufen sich bei dem Material der 5jährigen Kühe die Zahlenwerte der Streuung der mittleren Leistungen bei kleinen, mittelgrossen und grossen Herden auf $636 \pm 9,582 \pm 12$ und $620 \pm 19 \mathrm{~kg}$. Die gesamte Wandlung in den mittleren Leistungen ist also bei den kleinsten Herden am grössten gewesen.

Die Streuung der relativen Milchleistungen ist gewiss um so geringer, je kleiner die Herden sind. Die Unterschiede sind aber nicht so gross (Tabelle 5), dass sie ausreichten, die erhaltenen Ergebnisse zu erklären. Die Ursache kann also wohl nicht in der Ungenauigkeit der relativen Leistungen kleiner Herden liegen. Dass die relativen Werte als Indikatoren für die Rangordnung der Tiere bei Herden aller Grössen praktisch gesehen von gleicher Bedeutung sind, mag auch aus den Korrelationen der relativen Werte der Milch und des Fettprozents hervorgehen, Korrelationen, die bei allen Gruppen gleich gross sind.

Die Grösse des Anteils der Qualitätsunterschiede scheint wenigstens nicht deutlich von der Grösse der Mittelleistungsunterschiede abhängig zu sein (Tabelle 6). Dagegen ist die Streuung der als kgUnterschiede ausgedrückten relativen Werte der Tiere bei höherem Leistungsstand grösser als bei niedrigem. Umgekehrt wie bei dem Ergebnis von KorkмaN (7) scheint dies darauf hinzuweisen, dass die prozentualen relativen Werte zweckmässiger sind als die Differenzen in kg. Diese Auffassung wird auch dadurch gestützt, dass der Wert des Variationskoeffizienten, der zugleich die auf Grund der prozentualen relativen Leistungen festgestellte Streuung widerspiegelt, vielmehr abnimmt bei stiegendem Leistungsstand, wie es auch zu geschehen hat, wenn man annimmt, dass die Herden dabei auch qualitativ besser werden.

Die Differenzen in $\mathrm{kg}$ sind aber nicht nur leichter zu berechnen, sondern auch, besonders zusammen mit den mittleren Leistungen der Herden, einfacher anzuwenden als die prozentualen Werte, weswegen es angebracht sein könnte, bei praktischer Züchtungsarbeit zu ihrer Anwendung überzugehen. Die Unterschiede zwischen diesen auf verschiedene Weise berechneten relativen Leistungen dürften jedenfalls sehr gering sein.

Die entsprechendenVergleiche hinsichtlich des Fettgehaltes der Milch (Tabelle 7 und 8) zeigen, dass der durchschnittliche Anteil der Qualitätsunterschiede an den Gesamtunterschieden der mittleren 
Fettprozentsätze grösser ist als bei den Milchmengen. Dagegen hat die Grösse der Herden wenigstens keinen deutlichen Einfluss auf den Anteil der Qualitätsunterschiede ausgeübt. Je grösser aber der Unterschied in den mittleren Leistungen der Herden gewesen ist, desto grösser ist offenbar der Teil davon gewesen, der sich auf die Qualität gegründet hat (Tabelle 9). Auch scheint der Anteil der Qualität um so grösser zu sein, je höher der Stand des Fettgehaltes ist, um den es sich handelt (Tabelle 10). Die Ursache zu derartigen von der Milcherzeugung abweichenden Ergebnissen kann darin bestehen, dass an der Vererbung des Fettgehaltes die herrschenden Gene beträchtlich beteiligt sind, wie DiNkHAUSER (2) und Hammond (3) erklärt haben. Wenn es sich so verhält, sind die für den Anteil der Qualität aus den Mittelleistungsdifferenzen erhaltenen Ergebnisse vermutlich kleiner als in Wirklichkeit. Jedenfalls scheint das Ergebnis für das Verfahren zu sprechen, das bei der praktischen Züchtungsarbeit die Beuerteilung der Neigung zum Fettgehalt auf Grund der Fettprozentsätze als solcher, ohne Berechnung relativer Werte, vor sich geht. In dieser Hinsicht stützen die hier dargelegte Auffassung die früheren Untersuchungen desVerfassers (16), nach denen bei der auf die Erzeugungswerte gegründeten Auslese der Bullen die Fettprozentsätze als solche zu einer besser gelungenen Auslese führten als ihre relativen Werte.

Es sei angeführt, dass bei diesen früheren Untersuchungen in der Züchtung auf Neigung zur Milcherzeugung hingegen die relative Beurteilungsweise gegenüber der absoluten zu einer geglückteren Auslese zu führen schien. Eine Ausnahme bildete ein Vergleichsmaterial zwischen Muttertieren und Söhnen. Als nach den nunmehr erhaltenen Ergebnissen bei den Muttertieren des besagten Materials die Grösse ihrer Herden untersucht wurde, liess sich erkennen, dass sie ohne Ausnahme aus sehr grossen Herden waren - die durchschnittliche Anzahl der Kühe belief sich bei diesen auf 54, während sie bei den Kontrollherden in entsprechender Zeit durchschnittlich etwa 7.5 ausmachte. Die Erklärung lag also darin, dass, da die Muttertiere aus grossen Herden waren, bei denen an dem Zustandekommen der Unterschiede zwischen den mittleren Leistungen die Qualität der Tiere recht stark beteiligt ist, die auf die absoluten Leistungen der Mütter gegründete Auslese zu einem besser gelungenen Ergebnis führte als die ausschliesslich auf relative Werte gestützte.

Bei Anwendung der Untersuchungsergebnisse auf die Praxis ist zunächst zu berücksichtigen, dass der Mittelwert der Rasse in bezug auf den Anteil der qualitativen Unterschiede der Herden von der Verteilung der Tiere auf verschieden grosse Herden abhängig ist. Werden auf dieser Grundlage die Mittelwerte der finnischen Herdenrassen berechnet, so ergibt sich für die Ayrshirerasse der Wert 1/5 und für die finnische Landrasse 1/9. Bei Beurteilung der Qualität des einzelnen Tieres ist demgemäss neben den relativen Werten von den Unterschieden der mittleren Leistungen - entweder von den gegenseitigen Unterschieden der Herden oder von den Abweichungen der Herden vom Mittelwert der Rasse - je nach der Rasse 1/5-1/9 zu berücksichtigen. Bei Anwendung prozentualer relativer Werte sind die entsprechenden Werte 1/7 und 1/10. Zu den besten Ergebnissen gelangt man aber, wenn der Anteil der Qualitätsunterschiede bei jeder Grössenklasse der Herden mit den ihnen eigenen Verhältniszahlen berechnet wird, die, auf graphischem Wege berechnet, in Tabelle 11 angegeben sind. 